Plant Production Science

http:/www.journals.zu.edu.eg/journalDisplay.aspx?Journalld=1\&queryType=Master

\title{
EFFECT OF PREHARVEST APPLICATIONS OF CALCIUM, ANTI- ETHYLENE COMPOUNDS AND THEIR COMBINATIONS ON "CANINO" APRICOT FRUIT QUALITY AND STORABILITY
}

\author{
Neven M.N. Nagy* \\ Hort. Dept., Fac. Agric., Damanhour Univ., Egypt \\ Received: 08/07/2018 ; Accepted: 14/08/2018
}

\begin{abstract}
This study was conducted during two sequential seasons of 2015 and 2016 in a private orchard located in El-Khattaba District, Menoufia Governorate, Egypt to investigate the influence of calcium chloride $\left(\mathrm{CaCl}_{2}\right)$ at $2 \%$, anti-ethylene compounds namely Aminoethoxyvinylglycine (AVG) at $150 \mathrm{ppm}$ and 1- Methylcyclopropene (1-MCP) at $25 \mathrm{ppm}$ in addition to their combinations $\left(\mathrm{CaCl}_{2}\right.$ plus AVG, $\mathrm{CaCl}_{2}$ plus 1- MCP, AVG plus 1-MCP and finally $\mathrm{CaCl}_{2}$ plus AVG and 1-MCP, at the same concentrations) on fruit drop at harvest and yield as well as firmness, jelly pulp and other quality parameters of "Canino" apricot fruits during cold storage at $0^{\circ} \mathrm{C}$ and $90-95 \% \mathrm{RH}$ for one month. During 2015 and 2016 seasons, apricot trees were sprayed three times starting after full bloom, fruit setting and finally ten days before harvest. Quality of sprayed fruits was evaluated at harvest and every ten days of cold storage. The results showed that external browning, internal browning, jelly pulp, fresh weight loss, total sugars, total soluble solids (TSS), TSS to acidity ratio, carotene content were increased, while firmness, electrolyte leakage, vitamin C, acidity, chlorophylls a and b contents were decreased with the progress of cold storage duration. Furthermore, the results revealed that all used treatments reduced external and internal browning symptoms in addition to jelly pulp formation and fruit fresh weight loss. Moreover, the treatments lessened electrolyte leakage of fruits, retarded the loss of fruit firmness and were effective on keeping the physical and chemical qualities relative to the control treatment. Finally, this study indicated that the addition of $\mathrm{CaCl}_{2}$ to anti- ethylene compounds was more effective than the individual application of each compound on reducing fruit abscission, increasing average fruit weight and yield/tree at harvest plus retarding the loss of firmness, other physical and chemical qualities and prolonging the storability of "Canino" apricots stored at $0^{\circ} \mathrm{C}$, especially the combination of AVG and 1-MCP in the presence of $\mathrm{CaCl}_{2}$.
\end{abstract}

Key words: Apricot, calcium, AVG, 1- MCP, fruit drop, browning, jelly pulp, firmness, fruit quality, storage.

\section{INTRODUCTION}

Apricot (Prunus armeniaca L.) is one of the stone fruits that belongs to family Rosaceae and distinguished by a double sigmoid growth curve. Moreover, apricot fruits are very important not only for being inside several manufacturing processes like jam, canned juice and dried fruits but for considering them wealthy in nutritional value. Since, fruits are deemed a good source of vitamin A which helps in the enhancement of vision. In addition, apricot fruits are rich in fiber

\footnotetext{
* Corresponding author: Tel. : +201005059761

E-mail address: Neven_Nagy75@yahoo.com
}

and considered a treasure chest of natural antioxidants which protect human body from dangerous diseases such as cancer.

Moreover, apricot is a climacteric fruit meaning has high respiratory and metabolic rates and having an ethylene emission (Rubio and Infante, 2010). Rapid softening of apricot fruit is the most postharvest problem which limits its marketability (Chambory et al., 1995 ; Souty et al., 1995). Consequently, fruits are very susceptible to bruising and subsequent decay resulting in considerable loss after harvest. 
Fruits of apricot are classified as very perishable since their short life either on the shelf nearly 2- 3 days at room temperature or at cold storage (ranges between 2 to 4 weeks) depending on cultivar according to Ishaq et al. (2009).

Additional losses may occur due to some physiological disorders such as gel breakdown, flesh browning and loss of flavor especially at $5^{\circ} \mathrm{C}$ as compared with at $0^{\circ} \mathrm{C}$ (Kader et al., 1985).

Canino apricot cultivar has been succeeded especially in newly reclaimed lands under Egyptian conditions. Consumers desire "Canino" fruits due to its privileged quality, luscious flavor and velvety texture.

The above problems are linked to the fruit nature and mostly appear after harvest. On the other hand, there is a serious problem facing apricot producers, namely fruit drop either during June month or before harvesting due to the deficiency of water and the increase of temperature. This problem leads to a major loss of yield. Since, yield is determined by the number of attached fruits and their size but it is difficult to control on fruit size, where it requires manipulating pumping of considerable amount of carbohydrates. This stimulation is practically not feasible. Thus, retaining proper number of fruits on the tree till harvest is the most critical factor to gain large yield (Farag and Nagy, 2012). Relatively few attempts have been made to successfully solve these problems, for example Davenport et al. (1972) reported that using antitranspirants during a drought is the only mean of reducing plant deficit in "Hamawy" apricots. In the same trend, the application of Vapor gard, Kaolin and Green miracle was very effective on mitigating fruit drop of "Hamawy" apricot trees (Masoud, 2012).

Ethylene is considered as a natural ripening hormone, so accompanied fruit maturation and its action regulates the ripening process. Furthermore, it is associated with physiological and biochemical changes of fruits such as tissue softening. Ethylene links itself to its action site in the cell at a certain stage of ripening process to promote a succession of events resulting in ripeness and senescence according to Burg and Burg (1967) and Lelievre et al. (1997a).
The preharvest application of Aminoethoxyvinylglycine (AVG) has been effective on reducing ethylene production and delaying softening of the fruit (Bregoli $\boldsymbol{e t}$ al., 2002; Jobling et al., 2003).

1-Methylcyclopropene (1- MCP) is categorized as an ethylene inhibitor used for extending shelf life and maintaining quality of plant products (Dong et al., 2002). Moreover, 1- MCP retards fruit postharvest softening (Menniti et al., 2004). Furthermore, Osuna et al. (2005) reported that 1- MCP reduces maturation in plant cells, consequently increases the available time for proper storage.

Calcium, on the other hand, is essential to ensure the maintaining of selective permeability and membrane integrity. It is also well known that stability and rigidity in the cell wall are provided by calcium as an integral part of the cell wall (Haggag, 1987 ; El-Shemy, 1998). In the same way, calcium chloride is applied to conserve fruit quality, mitigate the incidence of physiological disorders (Salunkhe and Desai, 1984; Burns and Pressey, 1987; Magee et al., 2002).

According to the aforementioned, it is necessary to find the suitable methods to mitigate and delay the deterioration of "Canino" apricot fruits. Thus, the objectives of this study are to investigate treatments that could inhibit ethylene production such as AVG, inhibit ethylene action as 1-MCP or maintain the integrity of the cell wall and the plasma membrane such as calcium or their combinations on "Canino" apricots quality and their storability in addition to reducing fruit abscission.

\section{MATERIALS AND METHODS}

The present study was carried out during two sequential seasons of 2015 and 2016 on ten years old "Canino" apricot trees grown in a private orchard located in El-Khattatba District, Menoufia Governorate, Egypt. The trees were budded on local apricot rootstock, planted at $5 \times$ 5 meters, in a sandy soil, under drip irrigation, received the local agricultural practices applied in the orchard. Twenty four healthy trees and uniform in vigor, size plus fruit load, as possible were selected and the randomized complete blocks design was followed in this experiment. 
The trees were sprayed three times starting after full bloom (the second week of March), the second spray was after fruit setting (the first week of April), while the last one was done ten days before harvest (the last week of May). Seven treatments beside the control were investigated. Each treatment was replicated three times with one tree per each. Each tree in the block was sprayed using a hand sprayer to the point of run off with one of the following solutions: (1) Tap water as a control, (2) calcium chloride $\left(\mathrm{CaCl}_{2}\right)$ at $2 \%$, (3) Aminoethoxyvinylglycine (AVG) at $150 \mathrm{ppm}$, (4) 1-Methylcyclopropene (1- MCP) used as liquid at $25 \mathrm{ppm}$, (5) $\mathrm{CaCl}_{2}$ plus $\mathrm{AVG}$, (6) $\mathrm{CaCl}_{2}$ plus 1-MCP, (7) AVG plus 1- MCP and finally (8) $\mathrm{CaCl}_{2}$ plus AVG and 1- MCP, at the same concentrations. A non-ionic surfactant namely Tween-80 at $0.1 \%(V / V)$ was added to all solutions. Four shoots of about one inch diameter at the same height around all directions of each tree were labeled to monitor the percentage of fruit drop at harvest as following:

Total No. of fruitlets - No. of fruits at harvest Fruit drop $(\%)=\longrightarrow \times 100$

Total No. of fruitlets

Fruit yield $(\mathrm{Kg})$ of each experimental tree was also estimated. At harvest (the first week of June), seventy five apricot fruits at a hard mature stage (yellowish- green) were manually harvested from each tree (replicate) per treatment. The collected- treated fruits were healthy and uniform in color and form in addition to that, fruits were devoid of visible pathogen infection and mechanical damage. The fruits were rapidly transported to the laboratory, washed with tap water, surface sterilized by dipping for three minutes in $0.05 \%$ $(V / V)$ sodium hypochlorite, rinsed quickly in distilled water and then left to dry in the air. Fifteen fruits were taken to determine average fruit weight and initial fruit quality parameters at harvest (zero time before cold storage). In addition, fifteen fruits were taken to assess fresh weight loss percentage and the remaining forty five fruits (15/replicate) were used to periodically evaluate fruit quality at ten days intervals during storage. The fruits of each replicate were placed in a clean plastic plate and each three replicates per treatment were kept in a perforated cartoon box. Three perforated cartoon boxes were used for each treatment. All fruits were stored for a period of one month at $0^{\circ} \mathrm{C}$ (Abd El-Motty et al., 2007) and 90- 95\% $\mathrm{RH}$ in a commercial refrigerator. The shelf life assessment was not measured because apricot fruits are perishable (Ishaq et al., 2009) and had a very short shelf life. In addition, many investigators did not estimate it (MartinezRomero et al., 2000; Abd El-Motty et al., 2007; Shirzadeh et al., 2011; Abdrabboh, 2012; Sarfaraz et al., 2014; Yousefi et al., 2015; Al-Saikhan, 2018).

\section{Quality Assessment of Fruits}

\section{Determination of physical and chemical characteristics}

\section{External browning, internal browning and jelly pulp disorders (\%)}

The number of fruits had external browning or internal browning or jelly pulp was recorded at each sampling date and was calculated per each sample as a percentage of the total fruit number at the beginning of cold storage.

\section{Weight loss (\%)}

Apricot fruits were individually weighed and labeled before starting cold storage (initial weight) and at each sampling date of cold storage (10 days intervals), the difference of weight loss was estimated relative to the initial weight and weight loss percentage was calculated using the equation of Ghoname (1992).

\section{Fruit firmness (Newton)}

Firmness was measured as $\left(\mathrm{Ib} / \mathrm{in}^{2}\right)$ on the two opposite sides of apricot fruit using Effigi pressure tester at the tropic of the fruit (mod. Ft 327 ) and the values of readings were converted to Newton unit $\left(\mathrm{Ib} / \mathrm{in}^{2} \times 4.448\right)$.

\section{Electrolyte leakage (\%)}

It was calculated according to the technique of Ahrenes and Ingram (1988).

Freshly prepared juice of apricot fruits per each sample was extracted by using electric fruit juicer to determine the following measurements:

\section{Vitamin $C$ content}

It was measured and expressed as mg Lascorbic acid/100 $\mathrm{ml}$ fruit juice using the method described by AOAC (2000). 


\section{Total sugars (\%)}

Total sugars was extracted and determined by using the phenol- sulphuric acid colorimetric method according to Egan et al. (1987).

\section{Total soluble solids (TSS) content}

The percentage of TSS was measured as Brix at $20^{\circ} \mathrm{C}$ using a hand refractometer.

\section{Total acidity (\%)}

It was measured by titration with $0.1 \mathrm{~N}$ sodium hydroxide in the presence of phenolphthalein as an indicator (AOAC, 2000).

\section{TSS to acidity ratio}

It was calculated by dividing the TSS value on that of total acidity.

\section{Chlorophylls A and B Plus Total Carotene Contents}

The procedure of Wintermans and Mots (1965) to extract, assess and calculate the amount of chlorophylls $\mathrm{a}$ and $\mathrm{b}$ in addition to total carotene of apricot fruit peel which expressed as $\mathrm{mg} / 100 \mathrm{~g}$ fresh weight.

\section{Statistical Analysis}

The results of fruit drop, fruit weight and yield were laid out and analyzed as a randomized complete blocks design while the remaining results of this study were statistically analyzed using split plot in randomized complete blocks design as described by Steel and Torrie (1980). Analysis of variance was done and the least significant difference at 0.05 level was calculated by using Costat statistical software (Costat, 2008).

\section{RESULTS}

\section{Effect of Preharvest- Applied Treatments on Fruit Drop Percentage, Fruit Weight and Yield of "Canino" Apricot During 2015 and 2016 Seasons}

The results in Table 1 express the percentage of fruit drop in "Canino" apricot at harvest as affected by $\mathrm{CaCl}_{2}, \mathrm{AVG}, 1-\mathrm{MCP}$ and their combinations. The results indicated that the greatest reduction in fruit drop was recorded with applications of either AVG or 1-MCP alone or plus $\mathrm{CaCl}_{2}$ relative to that obtained with the control in a consistent manner for the two seasons. Moreover, $\mathrm{CaCl}_{2}$ plus 1-MCP combination was able to drastically reduce fruit drop in comparison with the sole application of 1- MCP. Meanwhile, there was an additive influence when $\mathrm{CaCl}_{2}$ was combined with AVG as compared with the individual treatment of either $\mathrm{CaCl}_{2}$ or $\mathrm{AVG}$ in terms of fruit drop at harvest.

Concerning, the effect of the single application of $\mathrm{CaCl}_{2}, \mathrm{AVG}, 1-\mathrm{MCP}$ and the efficacy of their combinations on "Canino" apricot average fruit weight as an important component of yield, the results in Table 1 show that the presence of $\mathrm{CaCl}_{2}$ alone or when incorporated with $\mathrm{AVG}$ either as an single component or combined with 1-MCP was the most effective on enhancing average fruit weight and this effect was similar to that obtained with the formulation containing AVG plus 1-MCP in both seasons. Furthermore, the influence of individual application of the two growth regulators, namely AVG and 1-MCP, on increasing average fruit weight was equally with that recorded with $1-\mathrm{MCP}$ treatment in the presence of $\mathrm{CaCl}_{2}$. On the contrary, the control treatment had the least apricot fruit weight in the two successive seasons.

As shown in Table 1, the use of preharvest application of $\mathrm{CaCl}_{2}, \mathrm{AVG}, 1-\mathrm{MCP}$ and their combinations played a significant influence on enhancement the average yield per tree at harvest relative to the control treatment which recorded the lowest fruit yield per tree. Meanwhile, the single use of 1-MCP and all 1-MCP- included formulations caused significantly the highest increase of fruit yield per tree in both seasons and the differences among them were exiguous and not significant. Furthermore, there was a positive effect of the combination containing $\mathrm{CaCl}_{2}$ plus $\mathrm{AVG}$ on improving fruit yield as compared with the sole application of each component. This pattern was similar in both seasons. 
Table 1. Effect of the preharvest- applied treatments on fruit drop percentage, average fruit weight and yield of "Canino" apricot during the two seasons (2015 and 2016)

\begin{tabular}{|c|c|c|c|c|c|c|}
\hline \multirow[t]{2}{*}{ Treatment } & \multicolumn{2}{|c|}{ Fruit drop (\%) } & \multicolumn{2}{|c|}{ Average fruit weight (g) } & \multicolumn{2}{|c|}{ Total yield (kg) } \\
\hline & 2015 & 2016 & 2015 & 2016 & 2015 & 2016 \\
\hline Control (Tap water) & $39.48 \mathrm{a}$ & $41.00 \mathrm{a}$ & $31.50 \mathrm{c}$ & $32.16 \mathrm{c}$ & $25.18 \mathrm{~d}$ & $27.31 \mathrm{~d}$ \\
\hline $\mathrm{CaCl}_{2}$ at $2 \%$ & $25.19 \mathrm{~b}$ & $25.67 \mathrm{~b}$ & $43.15 \mathrm{a}$ & $46.11 \mathrm{a}$ & $33.00 \mathrm{c}$ & $34.30 \mathrm{c}$ \\
\hline AVG at 150 ppm & $19.45 \mathrm{c}$ & $20.26 \mathrm{c}$ & $38.20 \mathrm{~b}$ & $39.00 \mathrm{~b}$ & $32.91 \mathrm{c}$ & $35.41 \mathrm{c}$ \\
\hline 1-MCP at 25 ppm & $10.70 \mathrm{e}$ & $11.48 \mathrm{e}$ & $38.38 \mathrm{~b}$ & $39.52 \mathrm{~b}$ & $40.92 \mathrm{a}$ & $41.08 \mathrm{a}$ \\
\hline $\mathrm{CaCl}_{2}+\mathbf{A V G}$ & $11.91 \mathrm{~d}$ & $13.17 \mathrm{~d}$ & $42.00 \mathrm{a}$ & $45.00 \mathrm{a}$ & $35.61 \mathrm{~b}$ & $37.45 \mathrm{~b}$ \\
\hline $\mathrm{CaCl}_{2}+1-\mathrm{MCP}$ & $7.00 \mathrm{f}$ & $7.52 \mathrm{f}$ & $38.31 \mathrm{~b}$ & $39.31 \mathrm{~b}$ & $41.00 \mathrm{a}$ & $42.34 \mathrm{a}$ \\
\hline AVG + 1- MCP & $4.11 \mathrm{~g}$ & $4.20 \mathrm{~g}$ & $42.17 \mathrm{a}$ & $45.29 \mathrm{a}$ & $41.51 \mathrm{a}$ & $41.22 \mathrm{a}$ \\
\hline $\mathrm{CaCl}_{2}+\mathrm{AVG}+1-\mathrm{MCP}$ & $3.55 \mathrm{~g}$ & $3.90 \mathrm{~g}$ & $42.22 \mathrm{a}$ & $44.91 \mathrm{a}$ & $41.96 \mathrm{a}$ & $42.22 \mathrm{a}$ \\
\hline
\end{tabular}

* Values, within the column, of similar letter(s) were not significantly different, when compared according to the least significant difference (LSD) at 0.05 level.

AVG: Aminoethoxyvinylglycine, 1-MCP (1-methylcyclopropene)

Effect of Preharvest-Applied Treatments, Cold Storage Duration and Their Interaction on Apricot Fruit Physical Characteristics During 2015 and 2016 Seasons

The results in Table 2 points to the effect of preharvest treatments on the percentage of external browning of apricots, regardless the effect of cold storage period. The results detected that the control treatment resulted in the highest significant values of external browning in comparison with other treatments in a consistent manner during 2015 and 2016 seasons. The individual treatment of $\mathrm{CaCl}_{2}$ or AVG caused lower percentages of external browning than the other combinations of $\mathrm{CaCl}_{2}$, AVG and 1-MCP which hindered the incidence of such browning in both seasons. On the other hand, 1-MCP treatment did not show a consistent trend regarding its effect where it retarded the formation of external browning only in the first season but gave lower percentage in the second season which did not significantly differ from that percentage obtained with AVG treatment.

As the storage period progressed, regardless the effect of treatments, it was found that the external browning of apricots was not yet visible until the first duration of cold storage. This browning started to appear after twenty days of storage and tented to increase gradually with significant values to the end of cold storage period in the two seasons (Table 2).

Concerning, the effect of the interaction between treatments and cold storage period, the results in Table 2 reveal that the binary combinations of AVG and 1- MCP alone or plus $\mathrm{CaCl}_{2}$ in addition to the formulation of the three compounds together were the most effective on inhibiting the incidence of external browning along the month of cold storage. This trend was consistent in both seasons. Meanwhile, the control fruits showed the opposite trend since they had the highest percentages of external browning during the two seasons.

With regard to the effect of the anti- ethylene compounds, namely $\mathrm{AVG}$ and 1-MCP alone or in the presence of $\mathrm{CaCl}_{2}$ in addition to $\mathrm{CaCl}_{2}$ alone, the results demonstrated in Table 3 declare that the highest increase of the percentage of internal browning in "Canino" apricots occurred with control treatment as compared with 1-MCP treatment alone or when combined with $\mathrm{CaCl}_{2}$, AVG or both which did not result in any symptoms of such browning.

The percentage of internal browning of apricots tended to significantly increase as the storage period at $0^{\circ} \mathrm{C}$ progressed, especially after 20 days. 
Table 2. Effect of the preharvest- applied treatments, cold storage periods and their interaction on external browning percentage of "Canino" apricot fruits during the two seasons (2015 and 2016)

\begin{tabular}{|c|c|c|c|c|c|c|c|c|c|c|}
\hline \multirow[t]{4}{*}{ Treatment } & \multicolumn{5}{|c|}{2015 season } & \multicolumn{5}{|c|}{2016 season } \\
\hline & \multicolumn{5}{|c|}{ External browning (\%) } & \multicolumn{5}{|c|}{ External browning (\%) } \\
\hline & \multicolumn{5}{|c|}{ Cold storage period (day) } & \multicolumn{5}{|c|}{ Cold storage period (day) } \\
\hline & $\mathbf{0}$ & 10 & 20 & 30 & Mean & $\mathbf{0}$ & 10 & 20 & 30 & Mean \\
\hline Control (Tap v & $0.00 \mathrm{f}$ & $0.00 \mathrm{f}$ & $17.77 \mathrm{~b}$ & $22.22 \mathrm{a}$ & $10.00 \mathrm{a}$ & $0.00 \mathrm{f}$ & $0.00 \mathrm{f}$ & $20.00 \mathrm{~b}$ & $24.44 a$ & $\overline{11.11 \mathrm{a}}$ \\
\hline $\mathrm{CaCl}_{2}$ at $2 \%$ & $0.00 \mathrm{f}$ & $0.00 \mathrm{f}$ & $11.11 \mathrm{~d}$ & $13.33 \mathrm{c}$ & $6.11 b$ & $0.00 \mathrm{f}$ & $0.00 \mathrm{f}$ & $6.67 \mathrm{~d}$ & $13.33 \mathrm{c}$ & $5.00 \mathrm{~b}$ \\
\hline AVG at $150 \mathrm{ppm}$ & $0.00 \mathrm{f}$ & $0.00 \mathrm{f}$ & $0.00 \mathrm{f}$ & $6.67 \mathrm{e}$ & $1.66 \mathrm{c}$ & $0.00 \mathrm{f}$ & $0.00 \mathrm{f}$ & $0.00 \mathrm{f}$ & $4.44 \mathrm{e}$ & $1.11 \mathrm{c}$ \\
\hline 1-MCP at 25 ppm & $0.00 \mathrm{f}$ & $0.00 \mathrm{f}$ & $0.00 \mathrm{f}$ & $0.00 \mathrm{f}$ & $0.00 \mathrm{~d}$ & $0.00 \mathrm{f}$ & $0.00 \mathrm{f}$ & $0.00 \mathrm{f}$ & $6.67 \mathrm{~d}$ & $1.66 \mathrm{c}$ \\
\hline $\mathrm{CaCl}_{2}+\mathrm{AVG}$ & $0.00 \mathrm{f}$ & $0.00 \mathrm{f}$ & $0.00 \mathrm{f}$ & $0.00 \mathrm{f}$ & $0.00 \mathrm{~d}$ & $0.00 \mathrm{f}$ & $0.00 \mathrm{f}$ & $0.00 \mathrm{f}$ & $0.00 \mathrm{f}$ & $0.00 \mathrm{~d}$ \\
\hline $\mathrm{CaCl}_{2}+1-\mathrm{MCP}$ & $0.00 \mathrm{f}$ & $0.00 \mathrm{f}$ & $0.00 \mathrm{f}$ & $0.00 \mathrm{f}$ & $0.00 \mathrm{~d}$ & $0.00 \mathrm{f}$ & $0.00 \mathrm{f}$ & $0.00 \mathrm{f}$ & $0.00 \mathrm{f}$ & $0.00 \mathrm{~d}$ \\
\hline AVG + 1- MCP & $0.00 \mathrm{f}$ & $0.00 \mathrm{f}$ & $0.00 \mathrm{f}$ & $0.00 \mathrm{f}$ & $0.00 \mathrm{~d}$ & $0.00 \mathrm{f}$ & $0.00 \mathrm{f}$ & $0.00 \mathrm{f}$ & $0.00 \mathrm{f}$ & $0.00 \mathrm{~d}$ \\
\hline $\mathrm{CaCl}_{2}+\mathrm{AVG}+1-\mathrm{MCP}$ & $0.00 \mathrm{f}$ & $0.00 \mathrm{f}$ & $0.00 \mathrm{f}$ & $0.00 \mathrm{f}$ & $0.00 \mathrm{~d}$ & $0.00 \mathrm{f}$ & $0.00 \mathrm{f}$ & $0.00 \mathrm{f}$ & $0.00 \mathrm{f}$ & $0.00 \mathrm{~d}$ \\
\hline Mean & $0.00 \mathrm{c}$ & $0.00 \mathrm{c}$ & $3.61 \mathrm{~b}$ & $5.27 \mathrm{a}$ & - & $0.00 \mathrm{c}$ & $0.00 \mathrm{c}$ & $3.33 b$ & $6.11 \mathrm{a}$ & - \\
\hline
\end{tabular}

* Values, within the characteristic, of similar letter(s) were not significantly different, when compared according to the least significant difference (LSD) at 0.05 level.

AVG: Aminoethoxyvinylglycine, 1-MCP (1-methylcyclopropene)

The results reported in Table 3 also indicate the effect of the interaction between various anti- ethylene compounds, calcium chloride and cold storage period in both seasons. The highest significant percentage of internal browning was recorded in the control after thirty days of cold storage relative to that obtained by $\mathrm{CaCl}_{2}$, AVG treatments and their combination. Actually, 1-MCP alone or when combined with $\mathrm{CaCl}_{2}$ or $\mathrm{AVG}$, even the triple combination was the most efficient on inhibition the incidence of internal browning in "Canino" apricot fruit flesh during both seasons.

From the illustrated results in Table 4, it could be noticed that the highest percentages of jelly pulp in both seasons were observed for the control fruits in comparison with those of other treatments. The opposite trend was achieved with 1- MCP when combined with $\mathrm{CaCl}_{2}$ and/or AVG where these treatments kept apricot pulp intact without incidence of jelly tissues in a consistent manner in both seasons. However, after twenty days of cold storage at $0^{\circ} \mathrm{C}$, the formation of jelly pulp in "Canino" apricots started to significantly increase achieving the highest percentage after thirty days of storage.

Table 4 also reported the percentage of jelly pulp of apricot fruits as affected with preharvest treatments and cold storage at $0^{\circ} \mathrm{C}$ for one month during the two seasons. The results obviously showed that after twenty days of storage, jelly pulp manifested in apricot fruits treated with $\mathrm{CaCl}_{2}, \mathrm{AVG}$ with lower percentages than that of the control. The highest percentage of jelly pulp was formed in control treatment relative to the sole application of $\mathrm{CaCl}_{2}, \mathrm{AVG}$ and 1- MCP. Actually, the combination of 1MCP plus $\mathrm{CaCl}_{2}$ or AVG, as well as the triple formulation completely prevented the incidence of jelly pulp of apricots during the whole period of cold storage. The results were consistent in the two seasons. 
Table 3. Effect of the preharvest-applied treatments, cold storage periods and their interaction on internal browning percentage of "Canino" apricot fruits during the two seasons (2015 and 2016)

\begin{tabular}{|c|c|c|c|c|c|c|c|c|c|c|}
\hline \multirow[t]{4}{*}{ Treatment } & \multicolumn{5}{|c|}{2015 season } & \multicolumn{5}{|c|}{2016 season } \\
\hline & \multicolumn{5}{|c|}{ Internal browning (\%) } & \multicolumn{5}{|c|}{ Internal browning (\%) } \\
\hline & \multicolumn{5}{|c|}{ Cold storage period (day) } & \multicolumn{5}{|c|}{ Cold storage period (day) } \\
\hline & $\mathbf{0}$ & 10 & 20 & 30 & Mean & $\mathbf{0}$ & 10 & 20 & 30 & Mean \\
\hline Control (Tap water) & $0.00 \mathrm{e}$ & $0.00 \mathrm{e}$ & $0.00 \mathrm{e}$ & $26.67 \mathrm{a}$ & $6.66 a$ & $0.00 \mathrm{e}$ & $0.00 \mathrm{e}$ & $22.26 b$ & $31.11 \mathrm{a}$ & $13.34 \mathrm{a}$ \\
\hline $\mathrm{CaCl}_{2}$ at $2 \%$ & $0.00 \mathrm{e}$ & $0.00 \mathrm{e}$ & $0.00 \mathrm{e}$ & $15.55 b$ & $3.88 \mathrm{ab}$ & $0.00 \mathrm{e}$ & $0.00 \mathrm{e}$ & $0.00 \mathrm{e}$ & $17.77 \mathrm{c}$ & $4.44 b$ \\
\hline AVG at 150 ppm & $0.00 \mathrm{e}$ & $0.00 \mathrm{e}$ & $0.00 \mathrm{e}$ & $13.33 b$ & $3.33 \mathrm{ab}$ & $0.00 \mathrm{e}$ & $0.00 \mathrm{e}$ & $0.00 \mathrm{e}$ & $20.00 \mathrm{~b}$ & $5.00 \mathrm{~b}$ \\
\hline 1-MCP at 25 ppm & $0.00 \mathrm{e}$ & $0.00 \mathrm{e}$ & $0.00 \mathrm{e}$ & $0.00 \mathrm{e}$ & $0.00 \mathrm{c}$ & $0.00 \mathrm{e}$ & $0.00 \mathrm{e}$ & $0.00 \mathrm{e}$ & $0.00 \mathrm{e}$ & $0.00 \mathrm{~d}$ \\
\hline $\mathrm{CaCl}_{2}+\mathbf{A V G}$ & $0.00 \mathrm{e}$ & $0.00 \mathrm{e}$ & $2.22 \mathrm{~d}$ & $4.44 c$ & $1.66 \mathrm{~b}$ & $0.00 \mathrm{e}$ & $0.00 \mathrm{e}$ & $0.00 \mathrm{e}$ & $6.67 \mathrm{~d}$ & $1.66 \mathrm{c}$ \\
\hline $\mathrm{CaCl}_{2}+1-\mathrm{MCP}$ & $0.00 \mathrm{e}$ & $0.00 \mathrm{e}$ & $0.00 \mathrm{e}$ & $0.00 \mathrm{e}$ & $0.00 \mathrm{c}$ & $0.00 \mathrm{e}$ & $0.00 \mathrm{e}$ & $0.00 \mathrm{e}$ & $0.00 \mathrm{e}$ & $0.00 \mathrm{~d}$ \\
\hline AVG + 1- MCP & $0.00 \mathrm{e}$ & $0.00 \mathrm{e}$ & $0.00 \mathrm{e}$ & $0.00 \mathrm{e}$ & $0.00 \mathrm{c}$ & $0.00 \mathrm{e}$ & $0.00 \mathrm{e}$ & $0.00 \mathrm{e}$ & $0.00 \mathrm{e}$ & $0.00 \mathrm{~d}$ \\
\hline $\mathrm{CaCl}_{2}+\mathrm{AVG}+1-\mathrm{MCP}$ & $0.00 \mathrm{e}$ & $0.00 \mathrm{e}$ & $0.00 \mathrm{e}$ & $0.00 \mathrm{e}$ & $0.00 \mathrm{c}$ & $0.00 \mathrm{e}$ & $0.00 \mathrm{e}$ & $0.00 \mathrm{e}$ & $0.00 \mathrm{e}$ & $0.00 \mathrm{~d}$ \\
\hline Mean & $0.00 \mathrm{~b}$ & $0.00 \mathrm{~b}$ & $0.27 b$ & $7.50 \mathrm{a}$ & - & $0.00 \mathrm{c}$ & $0.00 \mathrm{c}$ & $2.78 \mathrm{~b}$ & $9.44 \mathrm{a}$ & - \\
\hline
\end{tabular}

* Values, within the characteristic, of similar letter (s) were not significantly different, when compared according to the least significant difference (LSD) at 0.05 level.

AVG: Aminoethoxyvinylglycine, 1-MCP (1-methylcyclopropene)

Table 4. Effect of the preharvest- applied treatments, cold storage periods and their interaction on jelly pulp percentage of "Canino" apricot fruits during the two seasons (2015 and 2016)

\begin{tabular}{|c|c|c|c|c|c|c|c|c|c|c|}
\hline \multirow[t]{4}{*}{ Treatment } & \multicolumn{5}{|c|}{2015 season } & \multicolumn{5}{|c|}{2016 season } \\
\hline & \multicolumn{5}{|c|}{ Jellypulp (\%) } & \multicolumn{5}{|c|}{ Jellypulp (\%) } \\
\hline & \multicolumn{5}{|c|}{ Cold storage period (day) } & \multicolumn{5}{|c|}{ Cold storage period (day) } \\
\hline & $\mathbf{0}$ & 10 & 20 & 30 & Mean & $\mathbf{0}$ & 10 & 20 & 30 & Mean \\
\hline Control (Tap water) & $0.00 \mathrm{~h}$ & $0.00 \mathrm{~h}$ & $37.77 \mathrm{~b}$ & $48.89 a$ & $21.66 \mathrm{a}$ & $0.00 \mathrm{i}$ & $0.00 \mathrm{i}$ & $42.22 b$ & $55.55 a$ & $24.44 a$ \\
\hline $\mathrm{CaCl}_{2}$ at $2 \%$ & $0.00 \mathrm{~h}$ & $0.00 \mathrm{~h}$ & $26.67 \mathrm{~cd}$ & $28.89 \mathrm{c}$ & $13.89 b$ & $0.00 \mathrm{i}$ & $0.00 \mathrm{i}$ & $28.89 \mathrm{~cd}$ & $31.11 \mathrm{c}$ & $15.00 \mathrm{~b}$ \\
\hline AVG at 150 ppm & $0.00 \mathrm{~h}$ & $0.00 \mathrm{~h}$ & $17.77 \mathrm{e}$ & $22.22 \mathrm{de}$ & $10.00 \mathrm{c}$ & $0.00 \mathrm{i}$ & $0.00 \mathrm{i}$ & $20.00 \mathrm{e}$ & 24.44de & $11.11 \mathrm{c}$ \\
\hline 1-MCP at 25 ppm & $0.00 \mathrm{~h}$ & $0.00 \mathrm{~h}$ & $0.00 \mathrm{~h}$ & $4.44 f$ & $1.11 \mathrm{~d}$ & $0.00 \mathrm{i}$ & $0.00 \mathrm{i}$ & $0.00 \mathrm{i}$ & $6.67 f$ & $1.66 \mathrm{~d}$ \\
\hline $\mathrm{CaCl}_{2}+\mathbf{A V G}$ & $0.00 \mathrm{~h}$ & $0.00 \mathrm{~h}$ & $0.00 \mathrm{~h}$ & $2.22 \mathrm{~g}$ & $0.55 \mathrm{de}$ & $0.00 \mathrm{i}$ & $0.00 \mathrm{i}$ & $2.22 \mathrm{~h}$ & $4.44 \mathrm{~g}$ & $1.66 \mathrm{~d}$ \\
\hline $\mathrm{CaCl}_{2}+1-\mathrm{MCP}$ & $0.00 \mathrm{~h}$ & $0.00 \mathrm{~h}$ & $0.00 \mathrm{~h}$ & $0.00 \mathrm{~h}$ & $0.00 \mathrm{e}$ & $0.00 \mathrm{i}$ & $0.00 \mathrm{i}$ & $0.00 \mathrm{i}$ & $0.00 \mathrm{i}$ & $0.00 \mathrm{e}$ \\
\hline $\mathrm{AVG}+1-\mathrm{MCP}$ & $0.00 \mathrm{~h}$ & $0.00 \mathrm{~h}$ & $0.00 \mathrm{~h}$ & $0.00 \mathrm{~h}$ & $0.00 \mathrm{e}$ & $0.00 \mathrm{i}$ & $0.00 \mathrm{i}$ & $0.00 \mathrm{i}$ & $0.00 \mathrm{i}$ & $0.00 \mathrm{e}$ \\
\hline $\mathrm{CaCl}_{2}+\mathrm{AVG}+1-\mathrm{MCP}$ & $0.00 \mathrm{~h}$ & $0.00 \mathrm{~h}$ & $0.00 \mathrm{~h}$ & $0.00 \mathrm{~h}$ & $0.00 \mathrm{e}$ & $0.00 \mathrm{i}$ & $0.00 \mathrm{i}$ & $0.00 \mathrm{i}$ & $0.00 \mathrm{i}$ & $0.00 \mathrm{e}$ \\
\hline Mean & $0.00 \mathrm{c}$ & $0.00 \mathrm{c}$ & $10.27 \mathrm{~b}$ & $13.33 \mathrm{a}$ & - & $0.00 \mathrm{c}$ & $0.00 \mathrm{c}$ & $11.66 \mathrm{~b}$ & $15.27 \mathrm{a}$ & - \\
\hline
\end{tabular}

* Values, within the characteristic, of similar letter (s) were not significantly different, when compared according to the least significant difference (LSD) at 0.05 level.

AVG: Aminoethoxyvinylglycine, 1-MCP (1-methylcyclopropene) 
Effect of preharvest-used applications on weight loss of "Canino" apricots, regardless of the storage duration, was shown in Table 5. The control treatment significantly caused the highest increase of weight loss of apricots as compared with other treatments. However, the combinations among $\mathrm{CaCl}_{2}, \mathrm{AVG}$ and 1- MCP were significantly effective on reducing fruit weight loss in both seasons.

Weight loss of "Canino" apricot fruits was also influenced by cold storage duration (Table 5). The results indicated that fruit weight loss continued to increase as the storage period progressed and was significant even after ten days of cold storage relative to the initial weight of fruit.

The effect of preharvest applications on the percentage of weight loss of "Canino" apricots stored at $0^{\circ} \mathrm{C}$ for one month during both seasons was reported in Table 5. The lowest significant weight loss was found after the first ten days of storage in all used treatments as compared with the second and the third ten days of cold storage. The control treatment was greater in causing the highest weight loss of apricots after thirty days of cold storage relative to other treatments. In addition, the formulations of 1- MCP plus $\mathrm{CaCl}_{2}$ and/or AVG were still appreciated in reducing fruit weight loss after whole month of cold storage in a consistent pattern in both seasons.

The results referred to the effect of used antiethylene compounds and calcium chloride treatments on pulp firmness of "Canino" apricots, regardless cold storage period was presented in Table 6. This result clearly illustrated that the highest significant pulp firmness was found in fruits treated with the formulation of $\mathrm{CaCl}_{2}$ plus AVG and 1- MCP in both seasons. Moreover, all applied treatments also maintained higher pulp firmness than the control which had the lowest value of such firmness.

Pulp firmness of "Canino" apricots in relation to cold storage duration was shown in Table 6. It was evident from the results that the highest firmness of apricots pulp was detected at harvest. In other words, the initial value before storage (zero day) tended to significantly decrease as the cold storage period progressed.

Concerning the effect of used anti- ethylene compounds and calcium chloride treatments on pulp firmness of "Canino" apricot fruits stored at $0^{\circ} \mathrm{C}$ for one month, the results in Table 6 show that the higher values of firmness were recorded at the beginning of storage (zero time) for all applied treatments in comparison with other storage durations. At this time, the formulations consisted of $\mathrm{AVG}$ and 1-MCP alone or combined with $\mathrm{CaCl}_{2}$ resulted in the highest pulp firmness relative to other treatments. In addition, the control fruits had the lowest firmness value at the beginning or at the end of cold storage compared with other used treatments which were more effective on retarding the loss of pulp firmness. Moreover, the combinations of 1-MCP with $\mathrm{CaCl}_{2}$ and/ or AVG were capable of retarding the loss of such firmness which stayed comparable to those treated with $\mathrm{CaCl}_{2}$ or AVG treatments at the start of cold storage. The differences among the later treatments were not great enough to be significant and this pattern was consistent in the two successive seasons.

\section{Effect of Preharvest- Applied Treatments, Cold Storage Period and Their Interaction on Apricot Fruit Chemical Characteristics During 2015 and 2016 Seasons}

Response of electrolyte leakage to various preharvest treatments of "Canino" apricot fruits was recorded in Table 7. The results showed that control treatment gave a remarkable increase in electrolyte leakage as compared with all-other used treatments in both successive seasons. Furthermore, the formulation containing $\mathrm{CaCl}_{2}$ plus AVG and 1-MCP resulted in a considerable reduction in electrolyte leakage of fruit tissues in comparison with its application either alone or in combination of AVG or 1-MCP. Moreover, the combination of AVG plus 1-MCP was better in reducing the percentage of electrolyte leakage relative to the sole application of each one. This trend was consistent in both seasons.

Electrolyte leakage of Canino apricot cultivar as influenced by cold storage period at $0^{\circ} \mathrm{C}$ was indicated in Table 7. The results revealed that the progress of storage durations procured a great increase of electrolyte leakage since the highest significant percentage of such leakage was obtained at the end of cold storage. 
Table 5. Effect of the preharvest-applied treatments, cold storage periods and their interaction on weight loss percentage of "Canino" apricot fruits during the two seasons (2015 and 2016)

\begin{tabular}{|c|c|c|c|c|c|c|c|c|c|c|}
\hline \multirow[t]{4}{*}{ Treatment } & \multicolumn{5}{|c|}{2015 season } & \multicolumn{5}{|c|}{2016 season } \\
\hline & \multicolumn{5}{|c|}{ Weight loss (\%) } & \multicolumn{5}{|c|}{ Weight loss (\%) } \\
\hline & \multicolumn{5}{|c|}{ Cold storage period (day) } & \multicolumn{5}{|c|}{ Cold storage period (day) } \\
\hline & $\mathbf{0}$ & 10 & 20 & 30 & Mean & $\mathbf{0}$ & $\mathbf{1 0}$ & 20 & 30 & Mean \\
\hline $\begin{array}{l}\text { Control (Tap water) } \\
\text { (T) }\end{array}$ & $0.00 \mathrm{o}$ & $5.13 f$ & $10.10 \mathrm{~b}$ & $16.79 \mathrm{a}$ & $8.00 \mathrm{a}$ & $0.00 \mathrm{q}$ & $7.00 \mathrm{e}$ & $11.21 \mathrm{~b}$ & $18.23 \mathrm{a}$ & $9.11 \mathrm{a}$ \\
\hline $\mathrm{CaCl}_{2}$ at $2 \%$ & $0.00 \mathrm{o}$ & $2.48 \mathrm{~m}$ & $5.59 \mathrm{e}$ & $9.23 \mathrm{c}$ & $4.32 b$ & $0.00 \mathrm{q}$ & $3.691 \mathrm{~m}$ & $5.29 \mathrm{fg}$ & $10.50 \mathrm{c}$ & $4.87 \mathrm{~b}$ \\
\hline AVG at $150 \mathrm{ppm}$ & $0.00 \mathrm{o}$ & $2.45 \mathrm{~m}$ & 4.17hi & $7.00 \mathrm{~d}$ & $3.40 \mathrm{c}$ & $0.00 \mathrm{q}$ & $3.61 \mathrm{~m}$ & $5.11 \mathrm{ghi}$ & $7.98 \mathrm{~d}$ & $4.17 \mathrm{c}$ \\
\hline 1-MCP at 25 ppm & $0.00 \mathrm{o}$ & $2.16 \mathrm{mn}$ & $3.83 \mathrm{jk}$ & $4.60 \mathrm{~g}$ & $2.64 d$ & $0.00 \mathrm{q}$ & $3.21 \mathrm{no}$ & $4.56 \mathrm{j}$ & $5.42 \mathrm{f}$ & $3.29 \mathrm{e}$ \\
\hline $\mathrm{CaCl}_{2}+\mathrm{AVG}$ & $0.00 \mathrm{o}$ & $2.28 \mathrm{mn}$ & $4.00 \mathrm{ij}$ & $6.81 \mathrm{~d}$ & $3.27 \mathrm{c}$ & $0.00 \mathrm{q}$ & $3.39 \mathrm{mn}$ & $4.81 \mathrm{ij}$ & $7.69 \mathrm{~d}$ & $3.97 \mathrm{~d}$ \\
\hline $\mathrm{CaCl}_{2}+1-\mathrm{MCP}$ & $0.00 \mathrm{o}$ & $2.10 \mathrm{n}$ & $3.55 \mathrm{kl}$ & $4.72 \mathrm{~g}$ & $2.59 \mathrm{de}$ & $0.00 \mathrm{q}$ & $3.21 \mathrm{no}$ & $4.16 \mathrm{k}$ & $5.42 \mathrm{f}$ & $3.19 \mathrm{ef}$ \\
\hline AVG + 1- MCP & $0.00 \mathrm{o}$ & $2.00 \mathrm{n}$ & 3.411 & $4.51 \mathrm{~g}$ & $2.48 \mathrm{de}$ & $0.00 \mathrm{q}$ & $3.08 \mathrm{o}$ & $3.92 \mathrm{kl}$ & $5.23 \mathrm{fgh}$ & $3.05 f$ \\
\hline $\mathrm{CaCl}_{2}+\mathrm{AVG}+1-\mathrm{MCP}$ & $0.00 \mathrm{o}$ & $2.00 \mathrm{n}$ & 3.341 & $4.39 \mathrm{gh}$ & $2.43 \mathrm{e}$ & $0.00 \mathrm{q}$ & $2.57 \mathrm{p}$ & $3.51 \mathrm{mn}$ & $4.95 \mathrm{hi}$ & $2.75 \mathrm{~g}$ \\
\hline Mean & $0.00 \mathrm{~d}$ & $2.57 \mathrm{c}$ & $4.74 b$ & $7.25 \mathrm{a}$ & - & $0.00 \mathrm{~d}$ & $3.72 \mathrm{c}$ & $5.32 b$ & $8.17 \mathrm{a}$ & - \\
\hline
\end{tabular}

* Values, within the characteristic, of similar letter (s) were not significantly different, when compared according to the least significant difference (LSD) at 0.05 level.

AVG: Aminoethoxyvinylglycine, 1-MCP (1-methylcyclopropene)

Table 6. Effect of the preharvest- applied treatments, cold storage periods and their interaction on pulp firmness of "Canino" apricot fruits during the two seasons (2015 and 2016)

\begin{tabular}{|c|c|c|c|c|c|c|c|c|c|c|}
\hline \multirow[t]{4}{*}{ Treatment } & \multicolumn{5}{|c|}{2015 season } & \multicolumn{5}{|c|}{2016 season } \\
\hline & \multicolumn{5}{|c|}{ Pulp firmness (Newton) } & \multicolumn{5}{|c|}{ Pulp firmness (Newton) } \\
\hline & \multicolumn{5}{|c|}{ Cold storage period (day) } & \multicolumn{5}{|c|}{ Cold storage period (day) } \\
\hline & $\mathbf{0}$ & 10 & 20 & 30 & Mean & $\mathbf{0}$ & 10 & 20 & 30 & Mean \\
\hline$\overline{\text { Control (Tap water) }}$ & 24.801 & $21.86 \mathrm{~m}$ & 13.850 & $10.75 \mathrm{p}$ & $17.81 \mathrm{f}$ & $23.15 \mathrm{k}$ & $22.04 \mathrm{k}$ & 16.551 & $9.15 \mathrm{~m}$ & $17.72 \mathrm{f}$ \\
\hline $\mathrm{CaCl}_{2}$ at $2 \%$ & $30.17 \mathrm{fg}$ & $28.47 \mathrm{hij}$ & $27.83 \mathrm{ij}$ & $25.53 \mathrm{kl}$ & $28.00 \mathrm{~d}$ & $28.21 \mathrm{ef}$ & $25.67 \mathrm{ij}$ & $24.91 j$ & $23.24 \mathrm{k}$ & $25.50 \mathrm{~d}$ \\
\hline AVG at $150 \mathrm{ppm}$ & $30.21 \mathrm{fg}$ & $28.00 \mathrm{ij}$ & $22.15 \mathrm{~m}$ & $20.06 n$ & $25.10 \mathrm{e}$ & $28.00 \mathrm{efg}$ & $25.00 \mathrm{j}$ & $23.00 \mathrm{k}$ & 16.701 & $23.17 \mathrm{e}$ \\
\hline 1-MCP at 25 ppm & $34.12 \mathrm{bc}$ & $31.00 \mathrm{ef}$ & $30.17 \mathrm{fg}$ & $28.18 \mathrm{ij}$ & $30.86 \mathrm{c}$ & $31.86 \mathrm{c}$ & $29.00 \mathrm{de}$ & 27.21 fgh & $26.52 \mathrm{hi}$ & $28.64 b$ \\
\hline $\mathrm{CaCl}_{2}+\mathrm{AVG}$ & $31.39 \mathrm{ef}$ & 28.91ghi & $26.92 \mathrm{jk}$ & $25.88 \mathrm{kl}$ & $28.27 \mathrm{~d}$ & $29.92 \mathrm{~d}$ & $26.85 \mathrm{ghi}$ & 26.00hij & $23.00 \mathrm{k}$ & $26.44 \mathrm{c}$ \\
\hline $\mathrm{CaCl}_{2}+1-\mathrm{MCP}$ & $35.08 \mathrm{ab}$ & $33.09 \mathrm{~cd}$ & $30.00 \mathrm{fgh} 2$ & 28.89ghi & $31.76 \mathrm{~b}$ & $31.91 \mathrm{c}$ & $29.80 \mathrm{~d}$ & $27.09 \mathrm{fgh} 2$ & $26.98 \mathrm{fgh}$ & $28.94 b$ \\
\hline AVG + 1- MCP & $35.00 \mathrm{ab}$ & 32.51de & $31.51 \mathrm{ef} 2$ & 29.00ghi & $32.00 \mathrm{~b}$ & $33.52 \mathrm{ab}$ & $31.96 \mathrm{c}$ & $28.50 \mathrm{e} 2$ & 26.86ghi & $30.21 \mathrm{a}$ \\
\hline $\mathrm{CaCl}_{2}+\mathrm{AVG}+1-\mathrm{MCP}$ & $36.39 a$ & $34.00 \mathrm{bcd}$ & $31.52 \mathrm{ef}$ & $30.20 \mathrm{fg}$ & $33.02 \mathrm{a}$ & $34.69 \mathrm{a}$ & $33.30 \mathrm{~b}$ & $28.06 \mathrm{efg} 2$ & $26.98 \mathrm{fgh}$ & $30.75 \mathrm{a}$ \\
\hline Mean & $32.14 \mathrm{a}$ & $29.73 b$ & $26.74 \mathrm{c}$ & $24.81 \mathrm{~d}$ & - & $30.15 \mathrm{a}$ & $27.95 b$ & $25.16 \mathrm{c}$ & $22.42 \mathrm{~d}$ & - \\
\hline
\end{tabular}

* Values, within the characteristic, of similar letter (s) were not significantly different, when compared according to the least significant difference (LSD) at 0.05 level.

AVG: Aminoethoxyvinylglycine, 1-MCP (1-methylcyclopropene) 
Table 7. Effect of the preharvest-applied treatments, cold storage periods and their interaction on electrolyte leakage percentage of "Canino" apricot fruits during the two seasons (2015 and 2016)

\begin{tabular}{|c|c|c|c|c|c|c|c|c|c|c|}
\hline \multirow[t]{4}{*}{ Treatment } & \multicolumn{5}{|c|}{2015 season } & \multicolumn{5}{|c|}{2016 season } \\
\hline & \multicolumn{5}{|c|}{ Electrolyte leakage (\%) } & \multicolumn{5}{|c|}{ Electrolyte leakage (\%) } \\
\hline & \multicolumn{5}{|c|}{ Cold storage period (day) } & \multicolumn{5}{|c|}{ Cold storage period (day) } \\
\hline & $\mathbf{0}$ & 10 & 20 & 30 & Mean & $\mathbf{0}$ & 10 & 20 & 30 & Mean \\
\hline$\overline{\text { Control (Tap water) }}$ & $19.21 \mathrm{~g}$ & $24.17 \mathrm{~d}$ & $37.00 \mathrm{~b}$ & $42.42 \mathrm{a}$ & $30.70 \mathrm{a}$ & $21.39 \mathrm{~h}$ & $30.29 \mathrm{~d}$ & $40.28 \mathrm{~b}$ & $44.17 \mathrm{a}$ & $34.03 \mathrm{a}$ \\
\hline $\mathrm{CaCl}_{2}$ at $2 \%$ & $15.30 \mathrm{~h}$ & $19.81 \mathrm{~g}$ & $23.50 \mathrm{e}$ & $37.15 b$ & $23.94 b$ & $15.98 \mathrm{j}$ & $24.96 f$ & $28.57 \mathrm{e}$ & $38.22 \mathrm{c}$ & $26.93 b$ \\
\hline AVG at $150 \mathrm{ppm}$ & $10.17 \mathrm{n}$ & $14.50 \mathrm{i}$ & $22.35 f$ & $35.11 \mathrm{c}$ & $20.53 c$ & $10.97 p$ & $17.13 \mathrm{i}$ & $22.49 \mathrm{~g}$ & $25.53 \mathrm{f}$ & $19.03 \mathrm{c}$ \\
\hline $1-\mathrm{MCP}$ at $25 \mathrm{ppm}$ & $5.11 \mathrm{~s}$ & $9.17 \mathrm{o}$ & 11.111 & $11.91 \mathrm{k}$ & $9.32 \mathrm{e}$ & 5.93 tu & $8.54 \mathrm{r}$ & 11.61 no & $12.12 \mathrm{n}$ & $9.55 \mathrm{f}$ \\
\hline $\mathrm{CaCl}_{2}+\mathrm{AVG}$ & $9.00 \mathrm{o}$ & $10.891 \mathrm{~m}$ & $12.67 \mathrm{j}$ & $14.00 \mathrm{i}$ & $11.64 d$ & $9.88 \mathrm{q}$ & 11.49op & 14.671 & $15.37 \mathrm{jk}$ & $12.85 \mathrm{~d}$ \\
\hline $\mathrm{CaCl}_{2}+1-\mathrm{MCP}$ & $7.13 \mathrm{q}$ & $9.93 n$ & $13.20 \mathrm{j}$ & $14.49 \mathrm{i}$ & $11.18 \mathrm{~d}$ & $5.44 \mathrm{u}$ & 11.11op & $13.42 \mathrm{~m}$ & $15.13 \mathrm{kl}$ & $11.27 \mathrm{e}$ \\
\hline $\mathrm{AVG}+1-\mathrm{MCP}$ & $5.11 \mathrm{~s}$ & $7.99 \mathrm{p}$ & $10.26 \mathrm{mn}$ & 11.271 & $8.65 \mathrm{f}$ & 5.71 tu & $7.53 \mathrm{~s}$ & $10.00 \mathrm{q}$ & 11.61 no & $8.71 \mathrm{~g}$ \\
\hline $\mathrm{CaCl}_{2}+\mathrm{AVG}+1-\mathrm{MCP}$ & $4.32 \mathrm{t}$ & $6.00 \mathrm{r}$ & $8.20 \mathrm{p}$ & $9.00 \mathrm{o}$ & $6.88 \mathrm{~g}$ & $4.69 \mathrm{v}$ & $6.22 \mathrm{t}$ & $8.96 \mathrm{r}$ & $10.17 q$ & $7.51 \mathrm{~h}$ \\
\hline Mean & $9.41 \mathrm{~d}$ & $12.80 \mathrm{c}$ & $17.28 \mathrm{~b}$ & $21.91 \mathrm{a}$ & - & $9.99 \mathrm{~d}$ & $14.65 \mathrm{c}$ & $18.75 \mathrm{~b}$ & $21.54 \mathrm{a}$ & - \\
\hline
\end{tabular}

* Values, within the characteristic, of similar letter (s) were not significantly different, when compared according to the least significant difference (LSD) at 0.05 level.

AVG: Aminoethoxyvinylglycine, 1-MCP (1-methylcyclopropene)

The interaction between preharvest applications of various treatments and cold storage duration is shown in Table 7 in terms of their effect on electrolyte leakage of apricots. The results indicated that the significant reduction in the percentage of electrolyte leakage was found with all treatments as compared with the control, at the beginning of cold storage. Moreover, at this time (zero day) the formulation of $\mathrm{CaCl}_{2}$ plus AVG and 1-MCP resulted in the lowest electrolyte leakage in comparison with the sole or binary applications of each component. Meanwhile, the binary forms of $\mathrm{CaCl}_{2}$ with either AVG or 1-MCP were considerably effective on the reduction of electrolyte leakage as compared with the single application of $\mathrm{CaCl}_{2}$ or AVG. On the opposite side, 1- MCP alone or combined with AVG in dual formulation form had significantly similar effect on electrolyte leakage. Moreover, 1-MCP alone or with AVG treatments were effective on reducing the electrolyte leakage relative to other treatments. The highest percentage of electrolyte leakage was found with control treatment after thirty days of storage while the lowest significant reduction was recorded with $\mathrm{CaCl}_{2}$ plus AVG and 1-MCP. The last mentioned combination maintained apricot fruits integrity at the end of cold storage as those treated with $\mathrm{CaCl}_{2}$ plus AVG at harvest time (zero day). Finally, it could be reported that all applied treatments kept apricot fruits with lower electrolyte leakage after one month of storage at $0^{\circ} \mathrm{C}$ in comparison with the control.

Changes in vitamin C content of "Canino" apricot in relation to the effect of applied treatments were reported in Table 8 . The data revealed that the greatest vitamin $\mathrm{C}$ content was found in fruits treated with AVG plus 1- MCP as compared with that in the untreated fruits (control). Moreover, $\mathrm{AVG}$ and $\mathrm{CaCl}_{2}$ plus $1-\mathrm{MCP}$ treatments had a similar effect on vitamin $\mathrm{C}$ and caused a significant increase in such vitamin relative to the control. The least significant content of vitamin $\mathrm{C}$ was found in the control treatment in both seasons.

The influence of cold storage period on vitamin $\mathrm{C}$ content of apricots is shown in Table 8 . The results revealed that vitamin $\mathrm{C}$ content was significantly reduced with the progress of cold storage period recording the least content at the last ten days of storage. 
Table 8. Effect of the preharvest-applied treatments, cold storage periods and their interaction on vitamin C content of "Canino" apricot fruits during the two seasons (2015 and 2016)

\begin{tabular}{|c|c|c|c|c|c|c|c|c|c|c|}
\hline \multirow[t]{4}{*}{ Treatment } & \multicolumn{5}{|c|}{2015 season } & \multicolumn{5}{|c|}{2016 season } \\
\hline & \multicolumn{5}{|c|}{ Vitamin C (mg/100 ml juice) } & \multicolumn{5}{|c|}{ Vitamin C (mg/100 ml juice) } \\
\hline & \multicolumn{5}{|c|}{ Cold storage period (day) } & \multicolumn{5}{|c|}{ Cold storage period (day) } \\
\hline & $\mathbf{0}$ & 10 & 20 & 30 & Mean & $\mathbf{0}$ & 10 & 20 & 30 & Mean \\
\hline$\overline{\text { Control (Tap water) }}$ & $10.81 \mathrm{~h}$ & $8.00 \mathrm{q}$ & $7.13 \mathrm{r}$ & $5.27 \mathrm{~s}$ & $7.80 \mathrm{e}$ & 9.46ijkl & $9.15 \mathrm{klm}$ & $6.47 \mathrm{~s}$ & $4.95 \mathrm{t}$ & $7.50 \mathrm{e}$ \\
\hline $\mathrm{CaCl}_{2}$ at $2 \%$ & $13.00 \mathrm{a}$ & $10.95 \mathrm{~h}$ & $8.36 \mathrm{p}$ & $7.26 \mathrm{r}$ & $9.89 \mathrm{~d}$ & $11.96 \mathrm{a}$ & 9.39ijklm & $7.59 \mathrm{q}$ & $7.13 \mathrm{r}$ & $9.01 \mathrm{~d}$ \\
\hline AVG at $150 \mathrm{ppm}$ & $12.10 \mathrm{f}$ & $10.36 \mathrm{i}$ & $9.89 \mathrm{k}$ & $9.00 n$ & $10.33 b$ & $11.31 \mathrm{bcd}$ & $10.37 \mathrm{fg}$ & $9.00 \mathrm{~m}$ & $8.37 \mathrm{no}$ & $9.76 b$ \\
\hline 1-MCP at $25 \mathrm{ppm}$ & $12.85 \mathrm{ab}$ & $11.02 \mathrm{~h}$ & $10.20 \mathrm{ij}$ & $9.39 \mathrm{~m}$ & $10.86 \mathrm{a}$ & $11.09 \mathrm{cde}$ & 9.76hi & $9.51 \mathrm{ijk}$ & $9.081 \mathrm{~m}$ & $9.86 \mathrm{~b}$ \\
\hline $\mathrm{CaCl}_{2}+\mathrm{AVG}$ & $12.28 \mathrm{ef}$ & $10.00 \mathrm{jk}$ & $9.531 \mathrm{~m}$ & $8.27 \mathrm{p}$ & $10.02 \mathrm{~cd}$ & $11.59 \mathrm{ab}$ & $9.63 \mathrm{ij}$ & $8.57 \mathrm{n}$ & 7.89pq & $9.42 \mathrm{c}$ \\
\hline $\mathrm{CaCl}_{2}+1-\mathrm{MCP}$ & $12.55 \mathrm{~cd}$ & $10.13 \mathrm{j}$ & $9.61 \mathrm{~lm}$ & 8.750 & $10.26 \mathrm{bc}$ & $11.42 \mathrm{bc}$ & $10.38 \mathrm{fg}$ & $9.23 \mathrm{jklm}$ & 8.23 nop & $9.81 \mathrm{~b}$ \\
\hline AVG + 1- MCP & $12.70 \mathrm{bc}$ & $11.31 \mathrm{~g}$ & $10.41 \mathrm{i}$ & $9.39 \mathrm{~m}$ & $10.95 \mathrm{a}$ & $11.00 \mathrm{de}$ & $10.75 \mathrm{ef}$ & $10.24 \mathrm{~g}$ & $9.00 \mathrm{~m}$ & $10.24 \mathrm{a}$ \\
\hline $\mathrm{CaCl}_{2}+\mathrm{AVG}+1-\mathrm{MCP}$ & $12.35 \mathrm{de}$ & 9.641 & $9.00 \mathrm{n}$ & 8.680 & $9.91 \mathrm{~d}$ & $11.66 \mathrm{ab}$ & 10.08gh & $9.15 \mathrm{klm}$ & 8.11 op & $9.75 b$ \\
\hline Mean & $12.33 \mathrm{a}$ & $10.17 b$ & $9.26 \mathrm{c}$ & $8.25 \mathrm{~d}$ & - & $11.18 \mathrm{a}$ & $9.93 \mathrm{~b}$ & $8.72 \mathrm{c}$ & $7.84 \mathrm{~d}$ & - \\
\hline
\end{tabular}

* Values, within the characteristic, of similar letter (s) were not significantly different, when compared according to the least significant difference (LSD) at 0.05 level.

AVG: Aminoethoxyvinylglycine, 1-MCP (1-methylcyclopropene)

With regard to the effect of the interaction between preharvest treatments and cold storage duration of apricots, the results in Table 8 show that $\mathrm{CaCl}_{2}$ treatment caused a marked increase in vitamin $\mathrm{C}$ content comparing with control treatment which resulted in the least content of such vitamin at the beginning of storage in a consistent manner during the two seasons. As the storage period advanced, it was noticed after thirty days that apricots treated with 1-MCP either individually or plus AVG resulted in a similar content of vitamin $\mathrm{C}$ and this was even higher than other treatments. Moreover, the combinations of $\mathrm{CaCl}_{2}$ plus 1-MCP together or combined with AVG led to higher content of vitamin $\mathrm{C}$ after 30 days of cold storage as compared with untreated ones which had the least content of vitamin C. In general, all preharvest treatments were capable of inhibiting the breakdown of vitamin $\mathrm{C}$ with the progress of cold storage relative to the control in both seasons.

Assessment of total sugars content in "Canino" apricots as influenced by preharvest treatments with anti-ethylene compounds, calcium chloride and their combinations was recorded in Table 9. The results disclosed a considerable increase of total sugars with $\mathrm{CaCl}_{2}$ and control treatments relative to all-other applied treatments. The addition of $\mathrm{CaCl}_{2}$ to $1-\mathrm{MCP}$ was more beneficial in raising the content of total sugars when compared with the application of either 1-MCP or AVG treatments. Moreover, the inclusion of $\mathrm{CaCl}_{2}$ into the formulation of $\mathrm{AVG}$ plus 1-MCP resulted in increasing total sugars content than the binary combination of AVG plus 1- MCP.

There was a marked increase of total sugars content in apricot fruits stored at $0^{\circ} \mathrm{C}$ for one month, regardless of the treatments, with the advancement of storage period in a consistent manner during the two successive seasons (Table 9).

From the results shown in Table 9, it was proved that at the beginning of cold storage, calcium chloride plus AVG whether alone or plus 1-MCP and control treatments resulted in a high content of total sugars in comparison with other used applications. At the end of cold storage, control treatment possessed the highest content of total sugars which was significantly similar to that obtained by $\mathrm{CaCl}_{2}$ treatment. Furthermore, the differences between the sole 
Table 9. Effect of the preharvest-applied treatments, cold storage periods and their interaction on total sugars percentage of "Canino" apricot fruits during the two seasons (2015 and 2016)

\begin{tabular}{|c|c|c|c|c|c|c|c|c|c|c|}
\hline \multirow[t]{4}{*}{ Treatment } & \multirow{2}{*}{\multicolumn{5}{|c|}{\begin{tabular}{|c|}
2015 season \\
Total sugars $(\%)$ \\
\end{tabular}}} & \multicolumn{5}{|c|}{2016 season } \\
\hline & & & & & & & Tot & al sugars & $(\%)$ & \\
\hline & \multicolumn{5}{|c|}{ Cold storage period (day) } & \multicolumn{5}{|c|}{ Cold storage period (day) } \\
\hline & $\mathbf{0}$ & 10 & 20 & 30 & Mean & $\mathbf{0}$ & 10 & 20 & 30 & Mean \\
\hline Control (Tap water) & $9.53 \mathrm{fg}$ & $10.21 \mathrm{de}$ & $10.93 \mathrm{bc}$ & $11.35 \mathrm{a}$ & $10.50 \mathrm{a}$ & 8.001 & $9.31 \mathrm{~h}$ & $10.27 \mathrm{~d}$ & $11.00 \mathrm{a}$ & $9.64 b c$ \\
\hline $\mathrm{CaCl}_{2}$ at $2 \%$ & $9.40 \mathrm{fg}$ & $10.18 \mathrm{de}$ & $10.83 b c$ & $11.15 \mathrm{ab}$ & $10.39 \mathrm{ab}$ & $8.56 \mathrm{i}$ & $9.76 \mathrm{fg}$ & $10.65 \mathrm{bc}$ & $10.92 \mathrm{ab}$ & $9.97 \mathrm{a}$ \\
\hline AVG at $150 \mathrm{ppm}$ & $7.00 \mathrm{~m}$ & 7.611 & $8.13 \mathrm{k}$ & $8.81 \mathrm{ij}$ & $7.88 \mathrm{ef}$ & $6.81 \mathrm{n}$ & $7.00 n$ & $7.57 \mathrm{~m}$ & $8.51 \mathrm{ij}$ & $7.47 \mathrm{e}$ \\
\hline ppm & $\mathrm{m}$ & $7.83 \mathrm{kl}$ & $8.05 \mathrm{k}$ & $8.79 \mathrm{ij}$ & $7.95 \mathrm{e}$ & $6.61 \mathrm{n}$ & $6.92 n$ & $7.41 \mathrm{~m}$ & $8.34 \mathrm{ijk}$ & $7.32 \mathrm{e}$ \\
\hline $\mathrm{CaCl}_{2}+\mathrm{AVG}$ & $9.22 \mathrm{gh}$ & $10.00 \mathrm{e}$ & $10.79 \mathrm{c}$ & $11.00 \mathrm{bc}$ & $10.25 b c$ & $8.31 \mathrm{ijkl}$ & $9.73 \mathrm{fg}$ & $10.27 \mathrm{~d}$ & $10.88 \mathrm{ab}$ & $9.79 b$ \\
\hline $\mathrm{CaCl}_{2}+1-\mathrm{MCP}$ & $9.00 \mathrm{hi}$ & $9.56 \mathrm{f}$ & $10.00 \mathrm{e}$ & $10.91 \mathrm{bc}$ & $9.86 \mathrm{~d}$ & $8.17 \mathrm{kl}$ & $9.51 \mathrm{gh}$ & $9.73 \mathrm{fg}$ & $10.09 \mathrm{de}$ & $9.37 \mathrm{~d}$ \\
\hline $\mathrm{AVG}+1-\mathrm{MCP}$ & $7.00 \mathrm{~m}$ & 7.541 & $8.00 \mathrm{k}$ & $8.53 \mathrm{j}$ & $7.76 f$ & 6.130 & $6.85 n$ & $7.35 \mathrm{~m}$ & $8.24 \mathrm{jkl}$ & $7.14 \mathrm{f}$ \\
\hline $\mathrm{CaCl}_{2}+\mathrm{AVG}+1-\mathrm{MCP}$ & $9.28 \mathrm{fgh}$ & $10.00 \mathrm{e}$ & $10.40 \mathrm{~d}$ & $11.00 \mathrm{bc}$ & $10.17 \mathrm{c}$ & $8.12 \mathrm{kl}$ & $9.69 \mathrm{fg}$ & $9.91 \mathrm{ef}$ & $10.39 \mathrm{~cd}$ & $9.52 \mathrm{~cd}$ \\
\hline Mean & $8.44 d$ & $9.11 \mathrm{c}$ & $9.64 b$ & $10.19 \mathrm{a}$ & - & $7.58 \mathrm{~d}$ & $8.59 \mathrm{c}$ & $9.14 \mathrm{~b}$ & $9.79 \mathrm{a}$ & - \\
\hline
\end{tabular}

* Values, within the characteristic, of similar letter (s) were not significantly different, when compared according to the least significant difference (LSD) at 0.05 level.

AVG: Aminoethoxyvinylglycine, 1-MCP (1-methylcyclopropene)

application $\mathrm{CaCl}_{2}$ and $\mathrm{CaCl}_{2}$ plus $\mathrm{AVG}$ were not significant. The combinations of $\mathrm{CaCl}_{2}$ plus $1-\mathrm{MCP}$ alone or when combined with AVG were competent to give apricot fruits after thirty days of cold storage with similar total sugars content to that found of untreated ones after twenty days. Moreover, there was no added advantage of using AVG plus 1- MCP where the content of total sugars did not vary along the storage durations among this combination and the individual application of each component. This trend was only in the first season, but in the second one the sole application of AVG or 1-MCP was better than the binary application in increasing the content of total sugars. Generally, both the AVG and 1-MCP treatments had a comparable effect on the content of total sugars of apricots during the whole period of storage.

Results shown in Table 10 clearly disclose the effect of various preharvest- applied treatments on total soluble solids percentage of "Canino" apricots. The results revealed that the highest percentage of total soluble solids was found in untreated fruits in comparison with those treated with AVG plus 1-MCP which contained the lowest percentage of such total soluble solids. $\mathrm{CaCl}_{2}$ treatment increased the percentage of TSS relative to other treatments. Meanwhile, the addition of $\mathrm{CaCl}_{2}$ to any combination containing either $\mathrm{AVG}$ and/or 1-MCP was more effective on increasing the percentage of TSS as compared with the sole applications of AVG or 1-MCP. Furthermore, the percentage of TSS of apricots did not significantly vary between $\mathrm{AVG}$ and 1-MCP treatments. Moreover, the $\mathrm{CaCl}_{2}$ plus 1-MCP combination was similar to that mixed with AVG on its effect on total soluble solids percentage of apricots. This trend of results was consistent in both seasons of study.

With regard to the effect of cold storage period, regardless of the treatments, on the percentage of total soluble solids in apricot fruits stored at $0^{\circ} \mathrm{C}$ fore whole month, it was found that as the storage period increased, TSS also increased in a consistent manner in the two successive seasons. The significant increase of TSS percentage was appeared even in the first ten days of cold storage. Total soluble solids percentage tended to increase with the progress of cold storage duration reaching to the highest value at the end of cold storage (Table 10). 
Table 10. Effect of the preharvest-applied treatments, cold storage periods and their interaction on total soluble solids percentage of "Canino" apricot fruits during the two seasons (2015 and 2016)

\begin{tabular}{|c|c|c|c|c|c|c|c|c|c|c|}
\hline \multirow[t]{4}{*}{ Treatment } & \multicolumn{5}{|c|}{2015 season } & \multicolumn{5}{|c|}{2016 season } \\
\hline & \multicolumn{5}{|c|}{ TSS (Brix) } & \multicolumn{5}{|c|}{ TSS (Brix) } \\
\hline & \multicolumn{5}{|c|}{ Cold storage period (day) } & \multicolumn{5}{|c|}{ Cold storage period (day) } \\
\hline & $\mathbf{0}$ & 10 & 20 & 30 & Mean & $\mathbf{0}$ & 10 & 20 & 30 & Mean \\
\hline Control (Tap water) & $13.30 \mathrm{e}$ & $14.86 \mathrm{~b}$ & $15.00 \mathrm{~b}$ & $15.96 \mathrm{a}$ & $14.78 \mathrm{a}$ & 13.00de & $13.70 \mathrm{~b}$ & $14.00 \mathrm{~b}$ & $14.83 \mathrm{a}$ & $13.88 \mathrm{a}$ \\
\hline $\mathrm{CaCl}_{2}$ at $2 \%$ & $13.15 \mathrm{ef}$ & $13.66 \mathrm{~d}$ & $13.93 \mathrm{~cd}$ & $14.06 \mathrm{c}$ & $13.70 \mathrm{~b}$ & 13.00de & $13.23 \mathrm{~cd}$ & $13.80 \mathrm{~b}$ & $14.00 \mathrm{~b}$ & $13.50 \mathrm{~b}$ \\
\hline AVG at $150 \mathrm{ppm}$ & 11.50nop 1 & 11.70lmno & $11.80 \mathrm{klmn}$ & $12.00 \mathrm{jkl}$ & $11.75 \mathrm{e}$ & $11.30 \mathrm{k}$ & $11.66 \mathrm{ijk}$ & 11.80ghij & 12.00ghi & $11.69 \mathrm{~d}$ \\
\hline 1-MCP at 25 ppm & $11.0 \mathrm{y}$ & 11.46op & 11.80 & m & $11.56 \mathrm{e}$ & $11.23 \mathrm{k}$ & $11.40 \mathrm{jk}$ & 11.76hij & 11.93ghi & $11.58 \mathrm{de}$ \\
\hline $\mathrm{CaCl}_{2}+\mathbf{A V G}$ & $12.90 \mathrm{fg}$ & $13.00 \mathrm{efg}$ & $13.73 d$ & $13.93 \mathrm{~cd}$ & $13.39 \mathrm{c}$ & $12.86 \mathrm{de}$ & $13.00 \mathrm{de}$ & $13.56 \mathrm{bc}$ & $13.70 \mathrm{~b}$ & $13.28 \mathrm{~b}$ \\
\hline $\mathrm{CaCl}_{2}+1-\mathrm{MCP}$ & $12.10 \mathrm{jk}$ & $12.50 \mathrm{hi}$ & $12.83 \mathrm{fg}$ & $13.00 \mathrm{efg}$ & $12.60 \mathrm{~d}$ & 12.00ghi & $12.16 \mathrm{gh}$ & $12.66 \mathrm{ef}$ & $12.90 \mathrm{de}$ & $12.43 \mathrm{c}$ \\
\hline AVG + 1- MCP & $11.00 \mathrm{q}$ & $11.23 \mathrm{pq}$ & 11.56 no & $11.63 \mathrm{mno}$ & $11.35 \mathrm{f}$ & $11.23 \mathrm{k}$ & $11.30 \mathrm{k}$ & $11.43 \mathrm{jk}$ & 11.76hij & $11.43 \mathrm{e}$ \\
\hline $\mathrm{CaCl}_{2}+\mathrm{AVG}+1-\mathrm{MCP}$ & $12.20 \mathrm{ij}$ & $12.73 \mathrm{gh}$ & $12.86 \mathrm{fg}$ & $13.00 \mathrm{efg}$ & $12.70 \mathrm{~d}$ & 12.00ghi & $12.23 \mathrm{fg}$ & $12.66 \mathrm{ef}$ & $12.86 \mathrm{de}$ & $12.44 \mathrm{c}$ \\
\hline Mean & $12.15 \mathrm{~d}$ & $12.64 \mathrm{c}$ & $12.94 \mathrm{~b}$ & $13.18 \mathrm{a}$ & - & $12.07 \mathrm{~d}$ & $12.33 \mathrm{c}$ & $12.71 \mathrm{~b}$ & $13.00 \mathrm{a}$ & - \\
\hline
\end{tabular}

* Values, within the characteristic, of similar letter (s) were not significantly different, when compared according to the least significant difference (LSD) at 0.05 level.

AVG: Aminoethoxyvinylglycine, 1-MCP (1-methylcyclopropene)

Total soluble solids percentage of apricots as influenced by the interaction between various used treatments and cold storage period was expressed in Table 10. The results indicated that at the beginning of storage, due to the spraying with applied treatments, both $\mathrm{CaCl}_{2}$ and control treatments caused general increase of TSS values, relative to other treatments. Moreover, there was a further increase of TSS percentages by the addition of $\mathrm{CaCl}_{2}$ to AVG and 1-MCP combinations as compared with the individual application of each one. On the other hand, the lowest percentages of TSS were obtained by 1MCP treatment alone or combined with AVG which were significantly similar in their effect on TSS percentage during both seasons.

Table 11 discussed the effect of $\mathrm{CaCl}_{2}, \mathrm{AVG}$, 1-MCP and their formulations on the content of acidity in "Canino" apricots during both seasons. The results illustrated that untreated apricots had significantly the lowest acidity as compared with those treated with other treatments. Moreover, $\mathrm{CaCl}_{2}$ treatment plus all its combinations whether with AVG and/or 1-MCP were more effective on reducing acidity relative to the sole application of AVG or 1- MCP.
Acidity content of "Canino" apricots was also affected with cold storage duration, regardless the treatments. The results in Table 11 obviously indicate that acidity content of apricot took an opposite direction to that obtained with total soluble solids since such acidity tended to decrease gradually as the storage period progressed. The value of acidity content at the end of cold storage appeared significantly the highest relative to the initial value at the beginning of storage in a consistent manner during both seasons.

Changes in acidity content of "Canino" apricots as related to the interaction between used treatments and cold storage period were shown in Table 11. The results detected that at the initiation of storage, preharvest spraying with AVG plus 1-MCP treatment resulted in the highest acidity content of apricots as compared with other treatments. Moreover, there was a further increase in fruit acidity by the single application of either 1-MCP or AVG relative to their combination in the presence of $\mathrm{CaCl}_{2}$. On the other hand, calcium chloride treatment alone was efficient in decreasing acidity content of apricots as compared with other treatments except, 
Table 11. Effect of the preharvest-applied treatments, cold storage periods and their interaction on acidity content of "Canino" apricot fruits during the two seasons (2015 and 2016)

\begin{tabular}{|c|c|c|c|c|c|c|c|c|c|c|}
\hline \multirow[t]{4}{*}{ Treatment } & \multicolumn{5}{|c|}{2015 season } & \multicolumn{5}{|c|}{2016 season } \\
\hline & \multicolumn{5}{|c|}{ Acidity (g/100 ml juice) } & \multicolumn{5}{|c|}{ Acidity (g/100 ml juice) } \\
\hline & \multicolumn{5}{|c|}{ Cold storage period (day) } & \multicolumn{5}{|c|}{ Cold storage period (day) } \\
\hline & $\overline{0}$ & 10 & 20 & 30 & Mean & $\overline{\mathbf{0}}$ & 10 & 20 & 30 & $\overline{\text { Mean }}$ \\
\hline Control (Tap water) & $1.31 \mathrm{~m}$ & $0.94 \mathrm{r}$ & $0.76 \mathrm{~s}$ & $0.64 \mathrm{t}$ & $0.91 \mathrm{f}$ & $1.20 \mathrm{jk}$ & 0.93 op & $0.67 \mathrm{r}$ & $0.57 \mathrm{~s}$ & $0.84 \mathrm{~h}$ \\
\hline $\mathrm{CaCl}_{2}$ at $2 \%$ & $1.76 \mathrm{fg}$ & $1.54 \mathrm{j}$ & $1.29 \mathrm{mn}$ & $1.13 q$ & $1.43 \mathrm{e}$ & $1.51 \mathrm{~h}$ & $1.131 \mathrm{~m}$ & 0.97 no & $0.82 q$ & $1.10 \mathrm{~g}$ \\
\hline AVG at 150 ppm & $1.97 \mathrm{~b}$ & $1.89 \mathrm{~d}$ & $1.73 \mathrm{gh}$ & $1.65 \mathrm{i}$ & $1.81 \mathrm{c}$ & $1.82 \mathrm{c}$ & $1.57 \mathrm{~g}$ & $1.50 \mathrm{~h}$ & $1.43 \mathrm{i}$ & $1.58 \mathrm{c}$ \\
\hline 1-MCP at 25 ppm & $2.00 \mathrm{~b}$ & $1.91 \mathrm{~cd}$ & $1.86 \mathrm{de}$ & $1.83 \mathrm{e}$ & $1.90 \mathrm{~b}$ & $1.91 \mathrm{~b}$ & $1.80 \mathrm{~cd}$ & $1.76 \mathrm{de}$ & $1.71 \mathrm{e}$ & $1.79 b$ \\
\hline $\mathrm{CaCl}_{2}+\mathbf{A V G}$ & $1.81 \mathrm{ef}$ & $1.70 \mathrm{hi}$ & $1.48 \mathrm{k}$ & $1.20 \mathrm{op}$ & $1.54 \mathrm{~d}$ & $1.59 \mathrm{~g}$ & $1.20 \mathrm{jk}$ & $1.09 \mathrm{~m}$ & $0.99 n$ & $1.21 \mathrm{e}$ \\
\hline $\mathrm{CaCl}_{2}+1-\mathrm{MCP}$ & $1.89 \mathrm{~d}$ & 1.371 & $1.25 \mathrm{no}$ & $1.17 \mathrm{pq}$ & $1.42 \mathrm{e}$ & $1.65 \mathrm{f}$ & $1.23 \mathrm{j}$ & $1.16 \mathrm{kl}$ & $1.00 \mathrm{n}$ & $1.26 \mathrm{~d}$ \\
\hline $\mathrm{AVG}+1-\mathrm{MCP}$ & $2.08 \mathrm{a}$ & $2.00 \mathrm{~b}$ & $1.95 b c$ & $1.91 \mathrm{~cd}$ & $1.98 \mathrm{a}$ & $1.97 \mathrm{a}$ & $1.90 \mathrm{~b}$ & $1.83 \mathrm{c}$ & $1.79 \mathrm{~cd}$ & $1.87 \mathrm{a}$ \\
\hline $\mathrm{CaCl}_{2}+\mathrm{AVG}+1-\mathrm{MCP}$ & $1.89 \mathrm{~d}$ & $1.65 \mathrm{i}$ & 1.391 & $1.17 \mathrm{pq}$ & $1.52 \mathrm{~d}$ & $1.60 \mathrm{fg}$ & $1.15 \mathrm{kl}$ & $1.00 \mathrm{n}$ & $0.91 p$ & $1.16 \mathrm{f}$ \\
\hline Mean & $1.83 \mathrm{a}$ & $1.62 b$ & $1.46 \mathrm{c}$ & $1.33 \mathrm{~d}$ & - & $1.65 \mathrm{a}$ & $1.36 \mathrm{~b}$ & $1.24 \mathrm{c}$ & $1.15 \mathrm{~d}$ & - \\
\hline
\end{tabular}

* Values, within the characteristic, of similar letter (s) were not significantly different, when compared according to the least significant difference (LSD) at 0.05 level.

AVG: Aminoethoxyvinylglycine, 1-MCP (1-methylcyclopropene)

control which gave the least content of acidity. With the progress of cold storage period, it could be noticed that acidity of all treatments tended to decrease. By the end of storage, the combination of AVG plus 1-MCP resulted in the highest value of acidity which did not significantly vary from that obtained after twenty days relative to other treatments. Moreover, there was a considerable increase of fruit acidity by the sole application of either 1-MCP or AVG. $\mathrm{CaCl}_{2}$ alone was capable of reducing fruit acidity as compared with other treatments except the control treatment which resulted in the lowest significant reduction of fruit acidity in both seasons. The addition of $\mathrm{CaCl}_{2}$ to $\mathrm{AVG}$ and/or 1-MCP achieved an advantage in reducing acidity content in comparison with the individual application of AVG or 1-MCP. Furthermore, it could be observed that $\mathrm{CaCl}_{2}$ plus either AVG or 1-MCP had similar effect on fruit acidity in the two seasons.

The results introduced in Table 12 refer to the effect of preharvest treatments on the ratio between TSS and acidity of "Canino" apricots during 2015 and 2016 seasons. Control treatment recorded the highest values of such ratio during both seasons. Moreover, $\mathrm{CaCl}_{2}$-treated fruits had significantly higher TSS to acidity ratio as compared with those-treated with other treatments. The single applications of either AVG or 1-MCP led to higher ratio of TSS to acidity relative to their combinations with $\mathrm{CaCl}_{2}$ in a consistent manner in both seasons. Apricot fruits treated with 1-MCP had similar TSS to acidity ratio to those treated with its combination with AVG since the differences between these treatments were not big enough to be significant.

Concerning, the changes of the ratio between TSS and acidity in apricots after various storage durations at $0^{\circ} \mathrm{C}$ were recorded in Table 12 . The results reported that there was an obvious increase of TSS to acidity ratio after the first ten days and this ratio continued to rise as the storage period was prolonged to reach to the highest value by the end of cold storage. This pattern of TSS to acidity ratio was influenced by the changes of both TSS and acidity as expected, the increase of TSS to acidity ratio with the 
Table 12. Effect of the preharvest- applied treatments, cold storage periods and their interaction on total soluble solids to acidity ratio of "Canino" apricot fruits during the two seasons (2015 and 2016)

\begin{tabular}{|c|c|c|c|c|c|c|c|c|c|c|}
\hline \multirow[t]{4}{*}{ Treatment } & \multicolumn{5}{|c|}{2015 season } & \multicolumn{5}{|c|}{2016 season } \\
\hline & \multicolumn{5}{|c|}{ TSS / acidity (ratio) } & \multicolumn{5}{|c|}{ TSS / acidity (ratio) } \\
\hline & \multicolumn{5}{|c|}{ Cold storage period (day) } & \multicolumn{5}{|c|}{ Cold storage period (day) } \\
\hline & $\mathbf{0}$ & 10 & 20 & 30 & Mean & $\mathbf{0}$ & 10 & 20 & 30 & Mean \\
\hline Control (Tap water) & $10.17 \mathrm{~g}$ & $15.84 \mathrm{c}$ & $19.77 b$ & $24.95 \mathrm{a}$ & $17.68 \mathrm{a}$ & $10.85 \mathrm{~h}$ & $14.74 \mathrm{~d}$ & $20.92 b$ & $26.06 \mathrm{a}$ & $18.14 \mathrm{a}$ \\
\hline $\mathrm{CaCl}_{2}$ at $2 \%$ & $7.47 \mathrm{ij}$ & $8.88 \mathrm{~h}$ & $10.80 \mathrm{f}$ & $12.45 d$ & $9.90 \mathrm{~b}$ & $8.61 \mathrm{j}$ & $11.73 \mathrm{~g}$ & $14.22 \mathrm{de}$ & $17.07 \mathrm{c}$ & $12.91 \mathrm{~b}$ \\
\hline AVG at $150 \mathrm{ppm}$ & $5.84 \mathrm{pq}$ & $6.20 \mathrm{mnop}$ & $6.82 \mathrm{kl}$ & $7.28 \mathrm{ij}$ & $6.53 \mathrm{e}$ & $6.21 \mathrm{qrst}$ & $7.44 \mathrm{mn}$ & $7.86 \mathrm{klm}$ & $8.40 \mathrm{jk}$ & $7.48 \mathrm{e}$ \\
\hline 1-MCP at 25 ppm & $5.55 \mathrm{qr}$ & 6.00nopq & $6.34 \mathrm{mno}$ & $6.51 \mathrm{~lm}$ & $6.10 \mathrm{ef}$ & $5.88 \mathrm{st}$ & $6.34 \mathrm{qrs}$ & $6.68 \mathrm{opq}$ & 6.98nop & $6.47 \mathrm{f}$ \\
\hline $\mathrm{CaCl}_{2}+\mathbf{A V G}$ & $7.12 \mathrm{jk}$ & $7.65 \mathrm{i}$ & $9.29 \mathrm{~h}$ & $11.61 \mathrm{e}$ & $8.92 \mathrm{~cd}$ & 8.09jkl & $10.83 \mathrm{~h}$ & $12.46 \mathrm{f}$ & $13.84 \mathrm{e}$ & $11.30 \mathrm{c}$ \\
\hline $\mathrm{CaCl}_{2}+1-\mathrm{MCP}$ & $6.401 \mathrm{mn}$ & $9.13 \mathrm{~h}$ & $10.27 \mathrm{~g}$ & $11.11 \mathrm{f}$ & $9.23 \mathrm{c}$ & $7.28 \mathrm{mno}$ & $9.90 \mathrm{i}$ & $10.92 \mathrm{~h}$ & $12.90 \mathrm{f}$ & $10.25 \mathrm{~d}$ \\
\hline AVG + 1- MCP & $5.29 \mathrm{r}$ & $5.61 \mathrm{qr}$ & 5.93opq 6 & 10 mnop & $5.73 \mathrm{f}$ & $5.70 \mathrm{t}$ & $5.95 \mathrm{rst}$ & $6.25 \mathrm{qrst}$ & $6.58 \mathrm{pqr}$ & $6.12 \mathrm{f}$ \\
\hline $\mathrm{CaCl}_{2}+\mathrm{AVG}+1-\mathrm{MCP}$ & $6.451 \mathrm{mn}$ & $7.71 \mathrm{i}$ & $9.27 \mathrm{~h}$ & $11.11 \mathrm{f}$ & $8.63 \mathrm{~d}$ & $7.501 \mathrm{mn}$ & $10.64 \mathrm{~h}$ & $12.66 \mathrm{f}$ & $14.09 \mathrm{e}$ & $11.22 \mathrm{c}$ \\
\hline Mean & $6.78 \mathrm{~d}$ & $8.38 \mathrm{c}$ & $9.81 \mathrm{~b}$ & $11.39 \mathrm{a}$ & - & $7.51 \mathrm{~d}$ & $9.70 \mathrm{c}$ & $11.50 \mathrm{~b}$ & $13.24 \mathrm{a}$ & 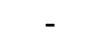 \\
\hline
\end{tabular}

* Values, within the characteristic, of similar letter (s) were not significantly different, when compared according to the least significant difference (LSD) at 0.05 level.

AVG: Aminoethoxyvinylglycine, 1-MCP (1-methylcyclopropene)

progress of cold storage duration was a result of the increase of TSS and the reduction of acidity. This trend was parallel in both seasons.

With respect to the effect of the interaction between treatments and cold storage durations on the ratio of TSS to acidity in "Canino" apricots, the results expressed in Table 12 show that control treatment had the greatest TSS to acidity ratio at the initiation of cold storage in both seasons. Meanwhile, $\mathrm{CaCl}_{2}$ alone or when added to AVG treatments resulted in higher TSS to acidity ratio than other ones. Furthermore, the addition of calcium chloride to whether AVG, 1-MCP or both caused higher values of TSS to acidity ratio as compared with the sole applications of either AVG or 1-MCP. At this time, it could be also noticed that the drastic reduction of TSS to acidity ratio was found by 1-MCP alone or when added to AVG which were significantly similar in their effect on such ratio in a consistent manner in the two successive seasons. Further increase of TSS to acidity ratio occurred with the advancement of cold storage durations in all applied treatments. By the end of storage period, the results proved that untreated fruits had the highest ratio of TSS to acidity in both seasons. There was a considerable increase of TSS to acidity ratio by $\mathrm{CaCl}_{2}$ treatment. Moreover, calcium chloridecontaining treatments were efficient in raising the ratio between TSS to acidity as compared the single application of the anti-ethylene compounds, namely AVG and 1-MCP. Conversely, 1-MCP treatment alone or when mixed with $\mathrm{CaCl}_{2}$ plus AVG produced apricot fruits with the lowest significant TSS to acidity ratio as compared with most treatments. This trend of results was consistent during both seasons.

The results concerning the changes in carotene content of "Canino" apricot fruits in response to all preharvest treatments was recorded in Table 13. In this matter, it could be noticed that the addition of $\mathrm{CaCl}_{2}$ to AVG produced apricot fruits with the highest content of carotene in both seasons which was similar to that found in fruits treated with $\mathrm{CaCl}_{2}$ individually and even to the control in the first season only. Meanwhile, the sole use of AVG was more effective on increasing carotene content of apricots than its supplement into a 
Table 13. Effect of the preharvest- applied treatments, cold storage periods and their interaction on carotene content of "Canino" apricot fruits during the two seasons (2015 and 2016)

\begin{tabular}{|c|c|c|c|c|c|c|c|c|c|c|}
\hline \multirow{4}{*}{ Treatment } & \multicolumn{5}{|c|}{2015 season } & \multicolumn{5}{|c|}{2016 season } \\
\hline & \multicolumn{5}{|c|}{ Carotene content $(\mathrm{mg} / \mathbf{1 0 0} \mathrm{g})$} & \multicolumn{5}{|c|}{ Carotene content $(\mathrm{mg} / \mathbf{1 0 0} \mathrm{g})$} \\
\hline & \multicolumn{5}{|c|}{ Cold storage period (day) } & \multicolumn{5}{|c|}{ Cold storage period (day) } \\
\hline & $\mathbf{0}$ & 10 & 20 & 30 & Mean & $\mathbf{0}$ & 10 & 20 & 30 & Mean \\
\hline$\overline{\text { Control (Tap water) }}$ & $2.95 \mathrm{~lm}$ & $3.19 \mathrm{ijk}$ & $3.85 \mathrm{~g}$ & $4.50 \mathrm{c}$ & $3.62 \mathrm{~b}$ & $2.831 \mathrm{~m}$ & $2.95 \mathrm{kl}$ & $3.77 \mathrm{~h}$ & $4.18 \mathrm{~cd}$ & $3.43 b c$ \\
\hline $\mathrm{CaCl}_{2}$ at $2 \%$ & $2.84 \mathrm{mn}$ & $3.27 \mathrm{ij}$ & $4.11 \mathrm{de}$ & $4.55 \mathrm{c}$ & $3.69 \mathrm{ab}$ & $2.73 \mathrm{mn}$ & $2.99 \mathrm{k}$ & $3.95 \mathrm{efg}$ & $4.30 \mathrm{c}$ & $3.49 \mathrm{~b}$ \\
\hline AVG at $150 \mathrm{ppm}$ & $2.39 \mathrm{op}$ & $3.17 \mathrm{jk}$ & $3.92 \mathrm{fg}$ & $4.19 \mathrm{~d}$ & $3.41 \mathrm{c}$ & $2.20 \mathrm{q}$ & $3.53 \mathrm{i}$ & $3.82 \mathrm{gh}$ & $4.07 \mathrm{de}$ & $3.40 \mathrm{~cd}$ \\
\hline 1-MCP at $25 \mathrm{ppm}$ & $2.35 \mathrm{pq}$ & $3.33 \mathrm{i}$ & $3.57 \mathrm{~h}$ & $4.10 \mathrm{de}$ & $3.33 \mathrm{~cd}$ & $2.18 \mathrm{qr}$ & $2.74 \mathrm{mn}$ & $3.29 \mathrm{j}$ & $4.00 \mathrm{ef}$ & $3.05 \mathrm{e}$ \\
\hline $\mathrm{CaCl}_{2}+\mathbf{A V G}$ & $2.70 \mathrm{n}$ & $3.16 \mathrm{jk}$ & $4.23 \mathrm{~d}$ & $4.81 \mathrm{~b}$ & $3.72 \mathrm{ab}$ & $2.67 \mathrm{no}$ & $3.07 \mathrm{k}$ & $3.86 \mathrm{gh}$ & $4.75 \mathrm{a}$ & $3.58 \mathrm{a}$ \\
\hline $\mathrm{CaCl}_{2}+1-\mathrm{MCP}$ & $2.30 \mathrm{pq}$ & $2.951 \mathrm{~m}$ & $3.58 \mathrm{~h}$ & $4.00 \mathrm{ef}$ & $3.20 \mathrm{e}$ & $2.22 \mathrm{q}$ & $3.08 \mathrm{k}$ & $4.00 \mathrm{ef}$ & $4.58 \mathrm{~b}$ & $3.47 \mathrm{bc}$ \\
\hline $\mathrm{AVG}+1-\mathrm{MCP}$ & $2.22 \mathrm{q}$ & $3.08 \mathrm{kl}$ & $3.86 f g$ & $4.00 \mathrm{ef}$ & $3.29 \mathrm{de}$ & $2.06 \mathrm{r}$ & $3.01 \mathrm{k}$ & $3.40 \mathrm{ij}$ & $3.91 \mathrm{fg}$ & $3.09 \mathrm{e}$ \\
\hline $\mathrm{CaCl}_{2}+\mathrm{AVG}+1-\mathrm{MCP}$ & $2.51 \mathrm{o}$ & $3.49 \mathrm{~h}$ & $4.20 \mathrm{~d}$ & $4.97 \mathrm{a}$ & $3.79 \mathrm{a}$ & $2.37 \mathrm{P}$ & $2.59 \mathrm{o}$ & $3.51 \mathrm{i}$ & $4.86 \mathrm{a}$ & $3.33 \mathrm{~d}$ \\
\hline Mean & $2.53 \mathrm{~d}$ & $3.20 \mathrm{c}$ & $3.91 \mathrm{~b}$ & $4.39 \mathrm{a}$ & - & $2.40 \mathrm{~d}$ & $2.99 \mathrm{c}$ & $3.70 \mathrm{~b}$ & $4.33 \mathrm{a}$ & - \\
\hline
\end{tabular}

* Values, within the characteristic, of similar letter (s) were not significantly different, when compared according to the least significant difference (LSD) at 0.05 level.

AVG: Aminoethoxyvinylglycine, 1-MCP (1-methylcyclopropene)

combination with 1-MCP. Conversely, 1-MCP treatment alone or added to $\mathrm{CaCl}_{2}$ in addition to the application of the three compounds together did not give a consistent effect on carotene content during both seasons.

The periodical sampling of stored apricots each ten days showed further significant increase of carotene content relative to the initial value (zero day). This increase was significant even after the first ten days of cold storage and continued until the end of cold storage achieving the highest content of carotene after thirty days.

With regard to the interaction between various preharvest treatments with $\mathrm{CaCl}_{2}, \mathrm{AVG}$, 1-MCP, their combinations and cold storage period on carotene content of apricots stored at $0^{\circ} \mathrm{C}$ for one month. The results revealed that the preharvest spray with $\mathrm{CaCl}_{2}$ and control treatments had similar carotene content which was higher in comparison with all other treatments at the beginning of cold storage. On the contrary, the AVG plus 1-MCP spray caused the lowest content of carotene at harvest (zero time). All used treatments caused a continuous increase of carotene content as the cold storage progressed.
Moreover, there was a noteworthy increase of carotene content by $\mathrm{CaCl}_{2}$ plus AVG and 1-MCP combination at the end of cold storage as compared with other treatments in both seasons. From the presented results, it could be also observed that the lowest carotene content was recorded by either 1-MCP as an individual application or when added to AVG.

The results in Table 14 indicate the effect of preharvest treatments with $\mathrm{CaCl}_{2}$, the anti- ethylene compounds $\mathrm{AVG}$ and 1-MCP in addition to their combinations on chlorophyll a content of "Canino" apricots. The results illustrated that the highest content of chlorophyll a was recorded by AVG plus 1-MCP treatment in a consistent manner during the two seasons. Furthermore, the individual application of either AVG or 1-MCP recorded higher content of chlorophyll a relative to $\mathrm{CaCl}_{2}$ when used in combinations with either AVG or 1-MCP in both seasons. On the other hand, the lowest content of chlorophyll a was found in fruits treated with $\mathrm{CaCl}_{2}$ in the two seasons. Comparing with the control, insignificant difference was recorded with the formulation containing $\mathrm{CaCl}_{2}$ plus AVG and 1$\mathrm{MCP}$ and this pattern was stable in both seasons. 
Table 14. Effect of the preharvest- applied treatments, cold storage periods and their interaction on chlorophyll a content of "Canino" apricot fruits during the two seasons (2015 and 2016)

\begin{tabular}{|c|c|c|c|c|c|c|c|c|c|c|}
\hline \multirow[t]{4}{*}{ Treatment } & \multicolumn{5}{|c|}{ Season 2015} & \multicolumn{5}{|c|}{ Season 2016} \\
\hline & \multicolumn{5}{|c|}{ Chlorophyll a content (mg/100 g) } & \multicolumn{5}{|c|}{ Chlorophyll a content (mg/100 g) } \\
\hline & \multicolumn{5}{|c|}{ Cold storage period (days) } & \multicolumn{5}{|c|}{ Cold storage period (days) } \\
\hline & $\overline{\mathbf{0}}$ & 10 & 20 & 30 & Mean & $\mathbf{0}$ & 10 & 20 & 30 & Mean \\
\hline$\overline{\text { Control (Tap water) }}$ & $1.100 \mathrm{f}$ & $0.095 \mathrm{jkl}$ & $0.067 \mathrm{mn}$ & 0.043 op & $0.326 \mathrm{e}$ & $1.070 \mathrm{f}$ & $0.095 \mathrm{ijkl}$ & 0.051 nop & 0.039 opqr & $0.313 \mathrm{c}$ \\
\hline $\mathrm{CaCl}_{2}$ at $2 \%$ & $1.150 \mathrm{e}$ & $0.088 \mathrm{kl}$ & $0.063 \mathrm{mno}$ & $0.041 \mathrm{p}$ & $0.335 \mathrm{de}$ & $1.000 \mathrm{~g}$ & $0.085 \mathrm{klm}$ & $0.056 \mathrm{n}$ & $0.035 \mathrm{qr}$ & $0.294 d$ \\
\hline AVG at $150 \mathrm{ppm}$ & $1.370 \mathrm{c}$ & 0.111ghij & $0.105 \mathrm{ijk}$ & $0.100 \mathrm{ijkl}$ & $0.421 \mathrm{~b}$ & $1.200 \mathrm{c}$ & $0.115 \mathrm{~h}$ & 0.103hij & $0.098 \mathrm{ijkl}$ & $0.379 b$ \\
\hline 1-MCP at 25 ppm & $1.400 \mathrm{~b}$ & $0.127 \mathrm{gh}$ & $0.118 \mathrm{ghi}$ & $0.105 \mathrm{ijk}$ & $0.437 \mathrm{a}$ & $1.220 \mathrm{~b}$ & $0.110 \mathrm{hi}$ & $0.102 \mathrm{hij}$ & 0.100hijk & $0.383 b$ \\
\hline $\mathrm{CaCl}_{2}+\mathrm{AVG}$ & $1.190 \mathrm{~d}$ & $0.100 \mathrm{ijkl}$ & $0.0831 \mathrm{~m}$ & $0.041 \mathrm{p}$ & $0.353 \mathrm{c}$ & $1.090 \mathrm{e}$ & $0.075 \mathrm{~m}$ & 0.053 no & $0.030 \mathrm{r}$ & $0.312 \mathrm{c}$ \\
\hline $\mathrm{CaCl}_{2}+1-\mathrm{MCP}$ & $1.180 \mathrm{~d}$ & 0.099ijkl & $0.057 \mathrm{nop}$ & $0.039 p$ & $0.343 \mathrm{~cd}$ & $1.100 \mathrm{e}$ & 0.092jkl & $0.058 \mathrm{n}$ & $0.033 \mathrm{r}$ & $0.320 \mathrm{c}$ \\
\hline AVG + 1- MCP & $1.430 \mathrm{a}$ & $0.131 \mathrm{~g}$ & 0.110hij & 0.103ijkl & $0.443 \mathrm{a}$ & $1.270 \mathrm{a}$ & $1.140 \mathrm{~d}$ & 0.100hijk & $0.094 \mathrm{jkl}$ & $0.651 \mathrm{a}$ \\
\hline $\mathrm{CaCl}_{2}+\mathrm{AVG}+1-\mathrm{MCP}$ & $1.120 \mathrm{f}$ & $0.101 \mathrm{ijkl}$ & $0.0831 \mathrm{~m}$ & $0.040 \mathrm{p}$ & $0.336 \mathrm{de}$ & $1.090 \mathrm{e}$ & $0.0831 \mathrm{~m}$ & 0.050 nopq & $0.037 \mathrm{pqr}$ & $0.315 \mathrm{c}$ \\
\hline Mean & $1.242 \mathrm{a}$ & $0.106 \mathrm{~b}$ & $0.085 \mathrm{c}$ & $0.064 \mathrm{~d}$ & - & $1.130 \mathrm{a}$ & $0.224 b$ & $0.071 \mathrm{c}$ & $0.058 \mathrm{~d}$ & - \\
\hline
\end{tabular}

* Values, within the characteristic, of similar letter (s) were not significantly different, when compared according to the least significant difference (LSD) at 0.05 level.

AVG: Aminoethoxyvinylglycine, 1-MCP (1-methylcyclopropene)

Concerning the relationship between chlorophyll a content of apricot fruits and cold storage duration, the results was assessed in Table 14. The results revealed that chlorophyll a content of apricots tended to decrease from one sampling time to another as compared with the initial value (zero day). Further reduction in chlorophyll a content was noticed by the end of cold storage after thirty days in a consistent manner in both seasons. Finally, it could be noticed that chlorophyll a of apricots took an opposite trend to that found with the carotene content.

Results of chlorophyll a content as influenced by the interaction between preharvest treatments and cold storage period was expressed in Table 14. The results showed that spraying of the combination containing AVG plus 1-MCP caused the highest content of chlorophyll a as compared with $\mathrm{CaCl}_{2}$ and control treatments which resulted in lower contents at the beginning of cold storage than other treatments. Moreover, at this time (zero day), the individual applications of either AVG or 1-MCP resulted in higher chlorophyll a content than $\mathrm{CaCl}_{2}$ treated with $\mathrm{AVG}$ and/or 1-
MCP. With the progress of cold storage period, all applied treatments tended to gradually decrease chlorophyll a content reaching to the lowest content which was recorded with calcium chloride treatment and its combinations in addition to the control treatment without any significant differences. Furthermore, the addition of AVG to 1-MCP had no added advantage on chlorophyll a relative to the single application of each component and all resulted in higher content of such chlorophyll as compared with other treatments.

Chlorophyll b content of "Canino" apricots as influenced by preharvest applications with calcium chloride, AVG, 1-MCP and their combinations was tabulated in Table 15. The results showed that the drastic increase in chlorophyll $\mathrm{b}$ was obtained by the combination containing AVG plus 1-MCP in a consistent manner during the two seasons. Conversely, the triple combination of $\mathrm{CaCl}_{2}$ plus $\mathrm{AVG}$ and 1-MCP caused lower value of chlorophyll $b$ as compared with other applied treatments and this value was similar to that of the control treatment only in the first season. The addition of $\mathrm{CaCl}_{2}$ to AVG was more effective on reducing chlorophyll $\mathrm{b}$ content than the individual application of AVG. 
Changes in chlorophyll $\mathrm{b}$ content of apricots stored at $0^{\circ} \mathrm{C}$ in response to cold storage durations were shown in Table 15. The results revealed that a significant reduction of chlorophyll $\mathrm{b}$ occurred after the first ten days relative to the initial value and this decline continued as the cold storage period was prolonged. By the end of cold storage, the chlorophyll b content was significantly lower than that of the initial one in a consistent manner in both seasons. Finally, it could be observed that chlorophyll $\mathrm{b}$ content took a similar trend to that obtained with the results of chlorophyll a in both seasons.

The results in Table 15 refer to the effect of the interaction between treatments and cold storage period on chlorophyll b content of "Canino" apricots. The results showed that at the zero time, the highest value of chlorophyll $b$ was found in apricots treated with AVG plus 1MCP in comparison with those of other treatments even with untreated fruits which contained the lowest value of such chlorophyll in both seasons. With the progress of cold storage duration, there was a considerable reduction of chlorophyll b content in all used treatments. At the end of cold storage after one month, the individual application of calcium chloride produced apricot fruits with similar content of chlorophyll $b$ to those treated with its combinations consisted of AVG alone or mixed with 1- MCP and even similar to untreated ones in both seasons. Moreover, this content was lower than that obtained with other treatments. The highest content of chlorophyll $b$ was recorded by the application of 1- MCP and its combination with AVG.

\section{DISCUSSION}

Finally, it was obvious that $\mathrm{CaCl}_{2}, \mathrm{AVG}, 1$ $\mathrm{MCP}$ and their combinations used as preharvest treatments were capable of drastically reducing fruit drop, increasing fruit weight consequently. The yield due to that fruit weight increase is a considerable outcome. In addition, all applied treatments decreased external and internal browning symptoms plus the mitigation of jelly pulp. Moreover, the treatments lessened electrolyte leakage of fruits, retarded the loss of fruit firmness and were effective on keeping the physical and chemical qualities relative to the control treatment. The above-mentioned disorders of fruits could be attributed to the effect of ethylene which results in genesis of abscission zone leading to increasing fruit drop and decreasing the yield. Furthermore, ethylene is classified as a ripening hormone since it regulates fruit ripening through binding to its action site in the cell and promotes successive events resulting in ripeness and senescence (Burg and Burg, 1967; Lelievre et al., 1997a). Apricot is a climacteric fruit that drastically increases the production of ethylene during ripening. The best effects of the applied treatments with regard to their ability of mitigation of abscission, maintaining fruit quality and extending fruit storability are mainly due to calcium. That calcium is an integral part of the cell wall since it can contribute to stability and the rigidity of the cell wall in addition to the maintaining of selective permeability or membrane integrity (Haggag, 1987; El-Shemy, 1998). Moreover, calcium salts used to increase $\mathrm{Ca}^{++}$content in the cell wall since there is an inverse relationship between calcium level of fruit tissue and the respiratory rate of fruits (Faust and Shear, 1972; Shirzadeh et al., 2011). In addition, calcium salts prevented physiological disorders, reduced the respiration, lessened the pectic substances solubilization, so maintained firmness and slowed down the process of ripening (Salunkhe and Desai, 1984; Burns and Pressey, 1987; Magee et al., 2002; Dunn and Able, 2006; Raese and Drake, 2006; Ishaq et al., 2009; Gayed et al., 2017). Furthermore, the presented results were in line with those obtained by El-Shazly et al. (2013) who indicated that the preharvest application of calcium increased yield, firmness and acidity of peach fruits. Abd El-Wahab (2015) also referred to that calcium nitrate increased fruit weight and yield at harvest, reduced weight loss and retarded the changes of firmness, TSS, acidity, total sugars and vitamin $\mathrm{C}$ of "Canino" apricots stored at $0^{\circ} \mathrm{C}$ for 4 weeks. The introduced results were in agreement with those found by Abd El-Motty et al. (2007) since reported that calcium chloride exhibited better yield and quality of "Canino" apricots stored at $0^{\circ} \mathrm{C}$ for forty days. 
Table 15. Effect of the preharvest- applied treatments, cold storage periods and their interaction on chlorophyll b content of "Canino" apricot fruits during the two seasons (2015 and 2016)

\begin{tabular}{|c|c|c|c|c|c|c|c|c|c|c|}
\hline \multirow[t]{4}{*}{ Treatment } & \multicolumn{5}{|c|}{2015 season } & \multicolumn{5}{|c|}{2016 season } \\
\hline & \multicolumn{5}{|c|}{ Chlorophyll b content (mg/100 g) } & \multicolumn{5}{|c|}{ Chlorophyll b content (mg/100 g) } \\
\hline & \multicolumn{5}{|c|}{ Cold storage period (day) } & \multicolumn{5}{|c|}{ Cold storage period (day) } \\
\hline & $\mathbf{0}$ & 10 & 20 & 30 & Mean & $\mathbf{0}$ & 10 & 20 & 30 & Mean \\
\hline Control (Tap water) & $0.823 \mathrm{~d}$ & $0.418 \mathrm{~g}$ & 0.1101 & $0.018 \mathrm{q}$ & $0.342 \mathrm{f}$ & $0.613 \mathrm{~d}$ & $0.300 \mathrm{~g}$ & 0.1551 & $0.017 \mathrm{o}$ & $0.271 \mathrm{e}$ \\
\hline $\mathrm{CaCl}_{2}$ at $2 \%$ & $0.841 \mathrm{c}$ & $0.419 \mathrm{fg}$ & $0.125 \mathrm{k}$ & $0.020 \mathrm{opq}$ & $0.351 \mathrm{~d}$ & $0.633 \mathrm{c}$ & $0.317 \mathrm{f}$ & $0.175 \mathrm{j}$ & 0.019 no & $0.286 \mathrm{c}$ \\
\hline AVG at $150 \mathrm{ppm}$ & $0.851 b$ & $0.423 \mathrm{f}$ & $0.131 \mathrm{j}$ & 0.023 nop & $0.357 \mathrm{c}$ & $0.642 b$ & $0.321 \mathrm{f}$ & $0.190 \mathrm{~h}$ & $0.023 \mathrm{mn}$ & $0.294 b$ \\
\hline 1-MCP at 25 ppm & $0.854 b$ & $0.428 \mathrm{e}$ & $0.139 \mathrm{i}$ & $0.025 \mathrm{mn}$ & $0.361 b$ & $0.666 \mathrm{a}$ & $0.327 \mathrm{e}$ & $0.194 \mathrm{~h}$ & $0.023 \mathrm{mn}$ & $0.302 \mathrm{a}$ \\
\hline $\mathrm{CaCl}_{2}+\mathrm{AVG}$ & $0.823 \mathrm{~d}$ & $0.421 \mathrm{fg}$ & $0.121 \mathrm{k}$ & $0.019 \mathrm{pq}$ & $0.346 \mathrm{e}$ & $0.630 \mathrm{c}$ & $0.300 \mathrm{~g}$ & $0.163 \mathrm{k}$ & 0.018 no & $0.277 \mathrm{~d}$ \\
\hline $\mathrm{CaCl}_{2}+1-\mathrm{MCP}^{-}$ & $0.841 \mathrm{c}$ & $0.419 \mathrm{fg}$ & $0.125 \mathrm{k}$ & 0.024 no & $0.352 \mathrm{~d}$ & $0.639 \mathrm{~b}$ & $0.321 \mathrm{f}$ & $0.182 \mathrm{i}$ & $0.020 \mathrm{mno}$ & $0.290 \mathrm{bc}$ \\
\hline $\mathrm{AVG}+1-\mathrm{MCP}$ & $0.862 \mathrm{a}$ & $0.430 \mathrm{e}$ & $0.155 \mathrm{~h}$ & $0.029 \mathrm{~m}$ & $0.369 \mathrm{a}$ & $0.666 \mathrm{a}$ & $0.329 \mathrm{e}$ & $0.191 \mathrm{~h}$ & $0.025 \mathrm{~m}$ & $0.302 \mathrm{a}$ \\
\hline $\mathrm{CaCl}_{2}+\mathrm{AVG}+1-\mathrm{MCP}$ & $0.823 \mathrm{~d}$ & $0.418 \mathrm{~g}$ & 0.1101 & $0.019 \mathrm{pq}$ & $0.342 \mathrm{f}$ & $0.628 \mathrm{c}$ & $0.300 \mathrm{~g}$ & $0.160 \mathrm{kl}$ & 0.018 no & $0.276 \mathrm{~d}$ \\
\hline Mean & $0.839 \mathrm{a}$ & $0.422 b$ & $0.127 \mathrm{c}$ & $0.022 \mathrm{~d}$ & - & $0.639 \mathrm{a}$ & $0.314 b$ & $0.176 \mathrm{c}$ & $0.020 \mathrm{~d}$ & - \\
\hline
\end{tabular}

* Values, within the characteristic, of similar letter (s) were not significantly different, when compared according to the least significant difference (LSD) at 0.05 level.

AVG: Aminoethoxyvinylglycine, 1-MCP (1-methylcyclopropene)

The use of anti- ethylene compounds namely AVG and 1-MCP acted on the control of abscission and retarded the deterioration of fruit quality and prolonged fruit storability. AVG inhibits ethylene synthesis by blocking the conversation of s-adenosyl methionine to 1-aminocyclopropane- 1-carboxcylic acid (ACC) which considered a precursor of ethylene (Yu and Yang, 1979). Moreover, the AVG preharvest treatment reduced ethylene production of peaches and nectarines, delayed fruit maturity and slowed down ripening events of fruits (Bregoli et al., 2002; Torrigiani et al., 2004; Cline, 2006). Furthermore, the obtained results were in line with those introduced by Torrigiani et al. (2004) who illustrated that AVG caused a reduction of ethylene production and modulated the ripening of nectarines.

On the other hand, 1-MCP has been shown to be a strong inhibitor of ethylene action and a ripening inhibitor since it links itself to the linking site of ethylene thus increases shelf life of several climacteric fruits (Lelievre et al., 1997 b; Sisler and Serek, 1997; Abdi et al.,
1998; Fan et al., 2000; Blankenship and Dole, 2003). Moreover, 1-MCP maintained firmness of apple and peach fruits (Fan et al., 1999; Cin et al., 2006). The introduced results also agreed with those obtained with Hayama et al. (2008) who indicated that treating peaches with AVG and 1-MCP retained ground color during ripening and delayed the ripening of peaches. Furthermore, 1-MCP treatment reduced weight loss and maintained firmness, titratable acidity and soluble solids content of fruits (Kurubas and Erkan, 2018).

Moreover, there was a reduction of acidity, vitamin $\mathrm{C}$, chlorophylls a and $\mathrm{b}$ while there were increases in weight loss, TSS, total sugars, peel carotene content with the progress of cold storage period. These results were in line with those obtained by Nagy (2000), Abd El-Motty (2007) and Abd El-Wahab (2015). Moreover, the reduction of firmness as the storage period prolonged agreed with that found by Hayama $\boldsymbol{e t}$ al. (2008). The decline of acidity during storage was mainly attributed to the occurrence of gluconeogenesis in fruit juice (Echeverria and 
Valich, 1989), consequently vitamin C (Lascorbic acid) was decreased as a part of acidity. However, the increase of total sugars that presented the major portion of TSS may be due to the hydrolysis of cell wall by some cell wall hydrolysis enzymes such as glycosidase and galatosidease (Echeverria and Ismail, 1990) and as a consequence led to firmness loss.

\section{Conclusion}

Finally, from the introduced results, it could be concluded that the addition of $\mathrm{CaCl}_{2}$ to antiethylene compounds, namely AVG and 1- MCP was more efficient than the individual and the binary applications of each compound on reducing fruit abscission, increasing fruit weight and yield at harvest plus maintaining firmness and other physical and chemical qualities consequently, extending the storability of "Canino" apricots stored at $0^{\circ} \mathrm{C}$.

\section{Recommendation}

From the results of this investigation, it could be recommended that spraying "Canino" apricot trees three times starting after full bloom, fruit setting and finally ten days before harvest with the combination of $150 \mathrm{ppm} A V G$ and $25 \mathrm{ppm}$ $1-\mathrm{MCP}$ in the presence of $2 \% \mathrm{CaCl}_{2}$ was effective on reducing fruit abscission, increasing fruit weight and yield at harvest plus keeping firmness, other physical and chemical qualities and prolonging the storability of "Canino" apricots stored at $0^{\circ} \mathrm{C}$.

\section{REFERENCES}

Abd El-Motty, E.Z., M.H. El-Shiekh, M.F.M. Shahin and M.I.F. Fawzy (2007). Effect of preharvest calcium and boric acid treatments on characteristics and storability of "Canino" apricot fruits. Res. J. Agric. and Biol. Sci., 3 (5): 430- 439.

Abd El-Wahab, S.M. (2015). Apricot postharvest fruit quality, storability and marketing in response to preharvest application. Middle East J. Agric., 4 (2): 347- 358.

Abdi, N., W.B. McGlasson, P. Holford, M. Williams and Y. Mizrahi (1998). Responses of climacteric and suppressed-climacteric plums to treatment with propylene and
1- methylcyclopropene. Postharvest Biol. and Technol., 14: 29- 39.

Abdrabboh, G.A. (2012). Effect of some preharvest treatments on quality of Canino apricot fruits under cold storage conditions. J. Hort. Sci. and Ornamental Pl., 4 (2): 227234.

Ahrenes, M.J. and D.L. Ingram (1988). Heat tolerance of citrus leaves. Hort. Sci., 23: 747748.

Al-Saikhan, M.S. (2018). Effect of calcium chloride dipping treatment on quality of Ziziphus spina- Christi L. fruits during cold storage. Afr. J. Agric. Res., 13 (16): 866- 871.

AOAC (2000). Association of Official Agriculture Chemists. Official Methods of Analysis Chemists. Washington, DC, USA.

Blankenship, S.M. and J.M. Dole (2003). 1-methylcyclopropene: a review. Postharvest Biol. Technol., 28 : 1- 25.

Bregoli, A.M., S. Scaramagli, G. Costa, E. Sabatini, V. Ziosi, S. Biondi and P. Torrigiani (2002). Peach (Pruns persica L.) fruit ripening: aminoethoxyvinylglycine (AVG) and exogenous polyamines affect ethylene emission and flesh firmness. Pl. Physiol., 114 : 472- 481 .

Burg, S.P. and E.A. Burg (1967). Molecular requirements for the biological activity of ethylene. Pl. Physiol., 42: 144- 152.

Burns, J.K. and R. Pressey (1987). $\mathrm{Ca}^{2+}$ in the cell wall of ripening tomato and peach. J. Ame. Soc. Hort. Sci., 112: 783- 787.

Chambory, Y., M. Souty, G. Jacquemin, R.M. Gomez and J.M. Audergon (1995). Research on the suitability of modified atmosphere packaging for shelf-life and quality improvement of apricot fruit. Acta Hort., 384: 633- 638 .

Cin, V.D., F.M. Rizzini, A. Botton and P. Tonutti (2006). The ethylene biosynthetic and signal transduction pathways are differently affected by 1- MCP in apple and peach fruit. Postharvest Biol. and Technol., 42: 125- 133. 
Cline, J.A. (2006). Effect of aminoethoxyvinylglycine and surfactants on preharvest drop, maturity, and fruit quality of two processing peach cultivars. Hort. Sci., 41: 377- 383 .

Costat (2008). Costat version 6.400, CoHort Software 798 Lighthouse Ave. PMB 320 Monterey, CA, 93940, USA.

Davenport, D.C., M.A. Fisher and R.M. Hagan (1972). Some counteractive effects of antitranspirants. P1. Physiol., 49: 722- 724.

Dong, L., S. Lurie and H.W.Y. Zhou (2002). Effect of 1- methylcyclopropene on ripening of "Canino" apricots and "Royal Zee" plums. Postharvest Biol. and Technol., 24: 135- 145.

Dunn, J.L. and A.J. Able (2006). Preharvest calcium effect on sensory quality and calcium mobility in strawberry fruit. Acta Hort., 708: 307-312.

Echeverria, E. and J. Valich (1989). Enzymes of sugar and acid metabolism in sorted "Valencia" oranges. J. Ame. Soc. Hort. Sci., 114: 445- 449 .

Echeverria, E. and M. Ismail (1990). Sugar unrelated to Brix changes in stored citrus fruits. Hort. Sci., 25: 710.

Egan, H., R.S. Kird and R. Sawyer (1987). Pearson's Chemical Analysis of Foods. Eighth Edition. Longman Scientific and Technical Essex $\mathrm{CM}_{20} .2 \mathrm{TE}$, England.

El-Shazly, S.M., A.M. Eisa, A.M.H. Moatamed and H.R.M. Kotb (2013). Effect of some Agro- chemicals preharvest foliar application on yield and fruit quality of "Swelling" peach trees. Alex. J. Agric. Res., 58 (3): 219229.

El-Shemy, M.A. (1998). Effect of some treatments on physical and chemical characteristics and storability of "Anna" apple fruits. Ph. D. Thesis, Tanta Univ., Fac. Agric., Hort. Dept. Kafr El-Sheikh, Egypt.

Fan, X., L. Argenta and J.P. Mattheis (2000). Inhibition of ethylene action by 1- methylcyclopropene prolongs storage life of apricots. Postharvest Biol. and Technol., 20: $135-142$
Fan, X., A. Apelbaum, E.C. Sisler and R. Goren (1999). 1-methylcyclopropene inhibits apple ripening. J. Ame. Soc. Hort. Sci., 124 : 690695.

Farag, K.M. and N.M.N. Nagy (2012). Effective reduction on postset and preharvest abscission and increasing the yield of "Washington" navel orange fruits by $1-\mathrm{MCP}, \mathrm{GA}_{3}$ and NAA. J. Appl. Sci. Res., 8 (10): 5132- 5141.

Faust, M. and Shear (1972). The effect of calcium on respiration of apples. J. Ame. Soc. Hort. Sci., 97: 437- 439.

Gayed, A.A.N.A., S.A.M.A. Shaarawi, M.A. Elkhishen and N.R.M. Elsherbini (2017). Pre- harvest application of calcium chloride and chitosan on fruit quality and storability of "Early Swelling" peach during cold storage. Ciencia e Agrotecnologia. 41 (2): 220- 231.

Ghoname, M.I. (1992). Effect of nitrogen, potassium and their interactions on quantitative, qualitative characteristics of some strawberries cultivars. Ph. D. Thesis, Fac. Agric., Alex. Univ., Egypt.

Haggag, M.N. (1987). Effect of preharvest and postharvest calcium treatments on storage behaviour of "Le Conte" pears. Alex. J. Agric. Res., 32 (3): 175- 188.

Hayama, H., M. Tatsuki and Y. Nakamura (2008). Combined treatment of aminoethoxyvinylglycine (AVG) and 1- methylcyclopropene (1-MCP) reduces melting- flesh peach fruit softening, 2008. Postharvest Biol. and Technol., 50: 228- 230.

Ishaq, S.H., A. Rathore, T. Masud and S. Ali (2009). Influence of postharvest calcium chloride application, ethylene absorbent and modified atmosphere on quality characteristics and shelf life of apricot (Prunus armeniaca L.) fruit during storage. Pak. J. Nut., 8 (6): 861- 865 .

Jobling, J.R., S.C. Morris, L. Mitchell and A.C. Rath (2003). The effect of ReTain growth regulator [aminoethoxyvinylglycine (AVG)] on the postharvest storage life of "Tegan Blue" plums. Aust. J. Agric., Victoria, 42 (5): 515- 518 . 
Kader, A.A., R.F. Kasmire, F.G. Mitchell, M.S. Reid, N.F. Sommer and J.F. Thompson (1985). Postharvest Technology of Horticultural Crops. The Regents of the Calif. Univ., Division Agric. and Nat. Res., California, USB, 192.

Kurubas, M.S. and M. Erkan (2018). Impacts of 1- methylcyclopropene (1-MCP) on postharvest quality of "Ankara" pears during long- term storage. Turkish J. Agric. and Forestry, 42: 88- 96.

Lelievre, J.M., A. Latche, B. Jones, M. Bouzayen and J.C. Pech (1997a). Ethylene fruit ripening. Physiologia Plantarum, 101 : 727739.

Lelievre, J.M., L. Tichit, P. Dao, L. Fillion, Y. W. Nam, J.C. Pech and A. Latche (1997b). Effects of chilling on the expression of ethylene biosynthetic genes in PasseCrassane pear (Pyrus communis L.) fruits. Plant Molec. Biol., 33: 847- 855.

Magee, R.L., F. Caporaso and A. Prakash (2002). Inhibiting irradiation induce of softening in diced tomatoes using calcium treatment. Session 30G, Fruit and vegetable Product: Processed fruits and vegetables. Annal meeting and Food Expo-Anaheim, California (Http: /www. ift. confex.com).

Martinez-Romero, D., D. Valero, M. Serrano, F. Burilo, A. Carbonell, L. BurGos and F. Riquelme (2000). Exogenous polyamines and gibberellic acid effects on peach (Prunus persica L.) storability improvement. J. Food Sci., 65 (2): 288- 293.

Masoud, A.A.B. (2012). Impact of some antitranspirants on yield and fruit quality of "Hamawy" apricot trees grown in sandy soils. Res. J. Agric. and Biol. Sci., 8 (2): 7882.

Menniti, A.M., R. Gregori and I. Donati (2004). 1-methylcyclopropene retards postharvest softening of plums. Postharvest Biol. Technol., 31: 269- 275.

Nagy, N.M.N. (2000). Effect of some natural acids and calcium on fruit quality and taste preservation of "Washington" navel orange after cold storage. Ph.D. Thesis. Alex. Univ., Egypt.
Osuna, J.A., J.A.Y. Beltran and M.A. Uriar (2005). Effect of 1-methylcyclopropene (1$\mathrm{MCP}$ ) on shelf life and quality of exporting mango. Revistafitotecnia. Mexicana., 28: 271- 278 .

Raese, J.T. and S.R. Drake (2006). Calcium foliar sprays for control of alfalfa greening cork spot, and hardened in "Anjou" pears. J. P1. Nut., 29 (3): 543- 552.

Rubio, P. and R. Infante (2010). Goldrich and "Robada" apricot (Prunus armeniaca L.) harvested at two different maturity stages. Acta. Hort., 682: 605- 626.

Salunkhe, D.K. and B.B. Desai (1984). Postharvest Biotechnology of Vegetables. CRC Press, Inc. Boca Raton Florida, USA. 55- 82.

Sarfaraz, F., A. Al-Bamerni and A.S. Abdulrhman (2014). Effect of storage period on quality characteristics of two cultivars of apricot (Prunus armeniaca L.). Int. J. Pure Appl. Sci. Technol., 20 (2): 27- 32.

Shirzadeh, E., V. Rabiel and Y. Sharafi (2011). Effect of calcium chloride $\left(\mathrm{CaCl}_{2}\right)$ on postharvest quality of apple fruits. Afr. J. Agric. Res., 6 (22): 5139- 5143.

Sisler, E.C. and M. Serek (1997). Inhibitors of ethylene response in plants at the receptors level: recent developments. Physiologia Plantarum. 100 : 577- 582.

Souty, M., M. Reich, L. Breulls, Y. Chambory, G. Jacquemin and J.M. Audergon (1995). Effect of postharvest calcium chloride treatments on shelf- life and quality of apricot fruit. Acta Hort., 384: 619- 623.

Steel, R.G.D. and T.H. Torrie (1980). Principles and Procedures of Statistics. (M.C. GrowHill, Co., USA).

Torrigiani, P., A.M. Bregoli, V. Ziosi, S. Scaramagli, T. Ciriaci, A. Rasari, S. Biondi and G. Costa (2004). Pre- harvest polyamine and aminoethoxyvinylglycine (AVG) applications modulate fruit ripening in Stark Red Gold nectarines (Prunus persica L. Batsch). Postharvest Biol. and Technol., 33: 293- 308.

Wintermans, J.F.M. and D.E. Mots (1965). Spectrophotometric characteristics of 
chlorophylls and their pheophytins in ethanol. Biochim Biophys Acta., 109 (2): 448- 453 .

Yousefi, S., M.E. Amiri and M. Mirabdulbaghi (2015). Biochemical properties and fruit quality of "Jahangiri" (Prunus armeniaca L.) apricot fruit under calcium chloride treatment. Cercetrai Agronomice in Moldova, XLVIII (4): 81- 94.

Yu, Y.B. and S.F. Yang (1979). Auxin- induced ethylene production and its inhibition by aminoethoxyvinylglycine and cobalt ion. Pl. Physiol., 64: 1074- 1077.

\title{
تأثير معاملات ما قبل القطف بالكالسيوم ومضادات الإيثيلين ومخاليطهم علي جودة ثمار المشمش "الكانينو" وقابليتها للتخزين الإين
}

\author{
نيفين محمد نبيه ناجي \\ قسم البساتين (فاكهة) ـ كلية الزر اعة - جامعة دمنهور - مصر لئين
}

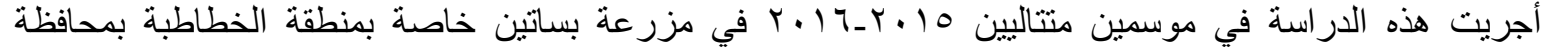

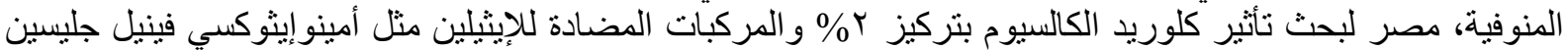

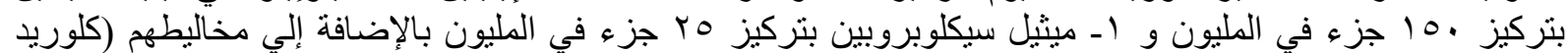

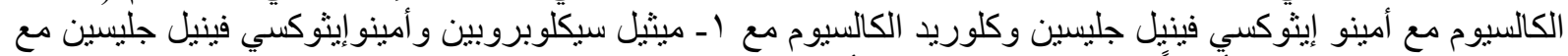

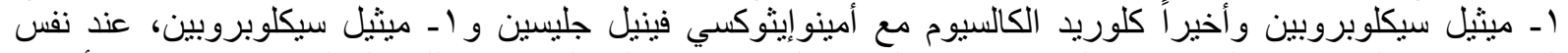

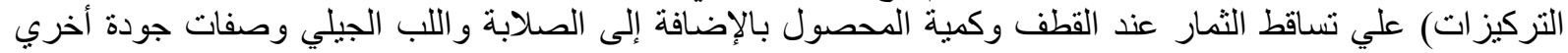

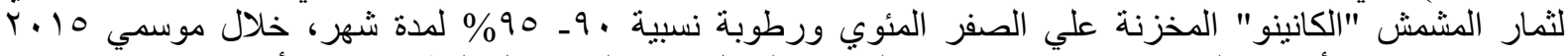

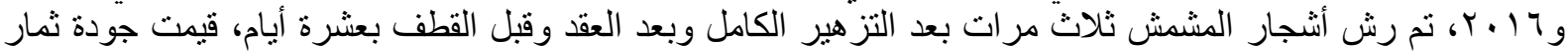

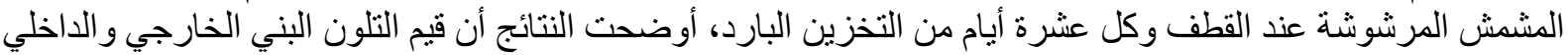

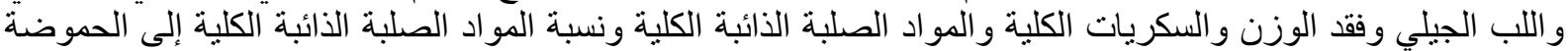

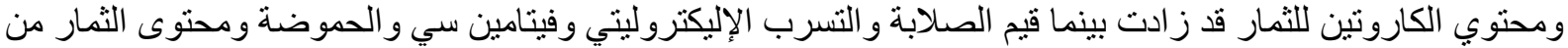

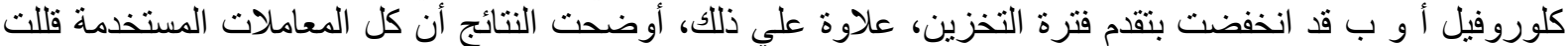

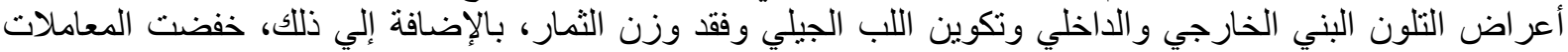

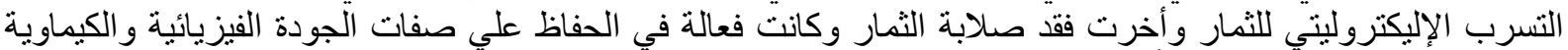

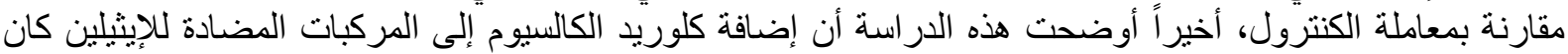

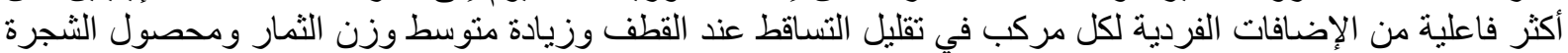

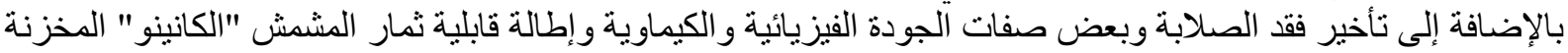
علي الصفر المئوي خاصة مخلوط أمينو إيثوكسي فينيل جليسين مع ا ـ ميثيل سيكلو بروبين في وجود كلوريد الكالسيو م.

أستاذ الفاكهة ـ قسم البساتين - كلية الزر اعة - جامعة دمنهور.

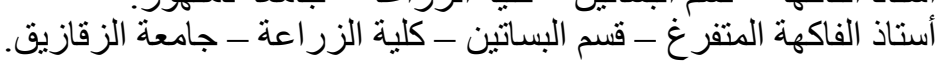

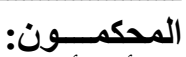

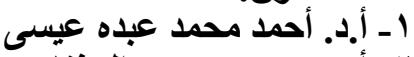

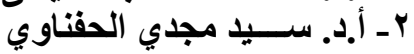

